\title{
Immunotherapy for pancreatic cancer: chasing the light at the end of the tunnel
}

\author{
Thomas P. Brouwer ${ }^{1,2} \cdot$ Alexander L. Vahrmeijer ${ }^{1}$ Noel F. C. C. de Miranda ${ }^{2}$ (D)
}

Accepted: 7 January 2021 / Published online: 12 March 2021

(C) The Author(s) 2021

\begin{abstract}
Background Checkpoint blockade immunotherapy has had a significant impact on the survival of a subset of patients with advanced cancers. It has been particularly effective in immunogenic cancer types that present large numbers of somatic mutations in their genomes. To date, all conventional immunotherapies have failed to produce significant clinical benefits for patients diagnosed with pancreatic cancer, probably due to its poor immunogenic properties, including low numbers of neoantigens and highly immune-suppressive microenvironments.

Conclusions Herein, we discuss advances that have recently been made in cancer immunotherapy and the potential of this field to deliver effective treatment options for pancreatic cancer patients. Preclinical investigations, combining different types of therapies, highlight possibilities to enhance anti-tumor immunity and to generate meaningful clinical responses in pancreatic cancer patients. Results from completed and ongoing (pre)clinical trials are discussed.
\end{abstract}

Keywords Pancreatic ductal adenocarcinoma $\cdot$ PDAC $\cdot$ Immunotherapy $\cdot$ Microenvironment $\cdot$ Checkpoint blockade $\cdot$ Stroma . combination therapies

\section{Introduction}

Pancreatic ductal adenocarcinoma (PDAC) is the most common form of pancreatic cancer and the seventh leading cause of cancer deaths in developed countries, with forecasts indicating a further escalation of mortality rates in the coming decade $[1,2]$. The 5-year survival rate of PDAC is $9 \%$ and is anticipated to remain dismal for years to come [3]. Chemotherapy and surgery have been the cornerstones of PDAC treatment over the past decades. Surgical resection is the only curative option, but it is only applicable in $20 \%$ of the patients due to disseminated disease at the time of diagnosis [4]. Gemcitabine has predominantly been used over the past decades as an (adjuvant) mono-therapy with limited benefit [5]. Adjuvant combination therapies, such as the addition of

Noel F. C. C. de Miranda

N.F.de Miranda@lumc.nl

1 Department of Surgery, Leiden University Medical Center, Leiden, The Netherlands

2 Department of Pathology, Leiden University Medical Center, Albinusdreef 2, 2333 ZA, Leiden, The NetherlandsPO Box 9600, $2300 \mathrm{RC}$ capecitabine or nanoparticle albumin bound (nab)-paclitaxel to gemcitabine and 5-fluorouracil, folonic acid, irinotecan and oxaliplatin (FOLFIRINOX), have improved overall survival compared to gemcitabine monotherapy and have become established treatment options [6-8]. More recently, these combination regimens have been implemented in a neoadjuvant setting to improve the chances of successful surgical resection of locally advanced PDAC [9]. Unfortunately, such combination therapies come at the cost of significant side effects whilst overall survival remains poor, warranting new treatment avenues.

The recent breakthrough of cancer immunotherapy has had a huge impact on the outcome of patients affected by therapyrecalcitrant cancer types such as advanced melanoma and non-small cell lung cancer (NSCLC) [10-12]. Targeting the immune checkpoint molecules programmed death 1 (PD-1), programmed death ligand 1 (PD-L1), and cytotoxic T lymphocyte antigen-4 (CTLA-4) leads to reinvigoration of antitumor immune responses in cancer patients and, consequently, improved clinical outcomes [13-16]. So far, immune checkpoint blockade, as mono- or combination therapy, has had a limited effect in PDAC, with the exception of patients diagnosed with mismatch repair-deficient cancers [17-21]. One of the most likely explanations for the obstinate nature 
of PDAC with respect to immunotherapy is that this tumor type is poorly immunogenic, with at least ten times less somatic mutations compared to melanoma and lung cancer. This translates into a scarcity of mutated antigens (neoantigens) that can be targeted by the patients' T cells [22]. Furthermore, the tumor microenvironment (TME) in PDAC plays a complex role in cancer progression and therapeutic response. Specifically, the PDAC TME is composed of a large stromal component consisting of cancer-associated fibroblasts, extracellular matrix, and immune cells with immune suppressive features that, most likely, also act as a barrier for drug delivery $[23,24]$.

Immunotherapy, however, may still hold potential to be used in a tailored manner for PDAC patients. Novel omicstechnologies are providing more profound insights into the tumorigenic and immunologic mechanisms at play in PDAC and, as such, may support rationale-based approaches [25, 26]. In this review, we will summarize which advances in immunotherapy may translate into improved PDAC treatment options. In addition, we will discuss which combinatorial approaches are likely to maximize the potential of immunotherapy and, thus, may serve as light at the end of the tunnel for PDAC patients.

\section{Enhancing knowledge of PDAC immune biology to improve immunotherapy outcomes}

PDAC combines a unique set of (intrinsic/extrinsic) features that makes it particularly challenging to tackle with immunotherapeutic approaches. In Fig. 1, a typical example of a PDAC TME is depicted: a large desmoplastic stroma that likely hampers drug delivery and immune cell infiltration, a low vessel density and a low abundance of immune cells. The poor immunogenicity of PDAC can, at least in part, be explained by a low mutation burden in cancer cells that fails the triggering of naturally occurring, cytotoxic immune responses $[23,27,28]$.

A number of studies has focused on dissecting the various components that underlie the complex biology of PDAC. Firstly, comprehensive genomic analyses have mapped the mutational and transcriptional landscape of PDACs. Activating mutations in the KRAS gene are ubiquitous as they are present in over $90 \%$ of PDACs, while also inactivation of the TP53 gene occurs frequently. Tumor suppressor genes such as SMAD4 and CDKN2A are also often mutated, albeit at lower frequencies [29, 30]. Further genomic analyses have revealed a 'long tail' of additional recurrent mutations/alterations in genes that belong to common pathways, including RAS signaling, TGF- $\beta$ signaling, WNT signaling, NOTCH signaling, cell cycle control, epigenetic regulation, and DNA damage repair, all with individual incidences below $10 \%[30,31]$. Tumors with a

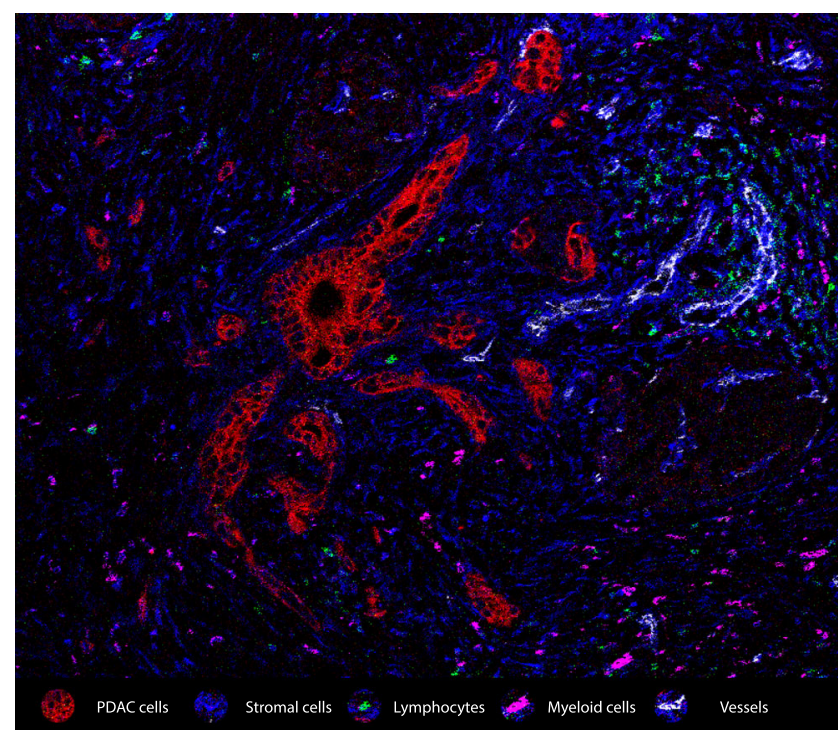

Fig. 1 Representative image of PDAC and its microenvironment. A high stromal content (vimentin, blue) surrounds malignant pancreatic ducts (red). Lymphocytic infiltration (CD3, green) is sparse and, generally, away from the tumor cells. Myeloid cells (CD68, purple) can be abundant and often possess immune suppressive features. All these factors, together with a poor vascularization, constitute major obstacles to the success of immunotherapeutic approaches in pancreatic cancer. The image was obtained through imaging mass cytometry analysis as reported before [183]

high mutation burden are uncommon in PDAC, as defects in DNA repair systems such as mismatch repair are scarce and PDAC development has not been associated with exposure to strong mutagenic carcinogens [32]. Mismatch repair deficiency was the first molecular feature to be granted a tissue-agnostic approval for cancer treatment, back in 2017, when pembrolizumab (an anti-PD-1 monoclonal antibody) was approved for the treatment of mismatch repair deficient tumors. Since then, this agent has shown an anti-tumor effect in mismatch repair deficient PDAC patients [21, 33]. DNA mismatch repair deficiency occurs in up to $1 \%$ of PDAC patients, rendering only a select group of patients eligible for anti-PD-1 therapy [34]. Of note, it has been suggested that BRCA1- and BRCA2deficient tumors could also be susceptible to checkpoint blockade immunotherapy due to the widespread propagation of DNA damage in these tumors $[32,35]$. Hereditary or somatic alterations in the $B R C A$ genes have also been described in PDAC patients, but whether they confer sensitivity to checkpoint blockade immunotherapy remains to be demonstrated [36]. Beyond mutation burden, transcriptional profiling has revealed the existence of different PDAC subtypes. Bailey and colleagues revealed a subtype with immunogenic features defined by upregulation of the CTLA-4- and PD1-encoding genes, thereby identifying a subgroup of patients that could potentially benefit from checkpoint blockade immunotherapy [37]. Other works using transcriptional profiling have, however, failed to identify such a potentially immunogenic subgroup [38, 39]. 
In recent years, the comprehensive characterization of immune cell populations that infiltrate tumor microenvironments has been essential to understand cancer immunity as well as to devise new immunotherapeutic strategies. Cytotoxic T cells play a central role in cancer immunity and immunotherapy. Their accumulation in tumor tissues is generally associated with a better patient prognosis and a better response to checkpoint blockade immunotherapies [13, 40, 41]. Although tumor infiltration by cytotoxic $\mathrm{T}$ cells has been associated with an improved overall survival in PDAC, the number of cytotoxic T cells in the PDAC tumor microenvironment has been found to be significantly lower compared to cancers with a more immunogenic profile [42-44]. $\mathrm{CD} 4+\mathrm{T}$ cells also play a fundamental role in the tumor immunity cycle and can differentiate into Th1, Th2, Th17 or Treg subsets. Th1 cells support anti-tumor responses through the production of cytokines such as IL-2 or IFN- $\gamma$. On the other hand, CD4+ T cells with a Th2 phenotype are sources of IL-4, IL-5 and IL-6, and induce humoral responses rather than cytotoxic ones [45]. During PDAC disease progression, a shift from predominantly Th1 to Th2 responses has been reported, thereby curtailing potential cytotoxic responses and promoting PDAC immune escape $[46,47]$. Another driving force behind CD4+ T cell-mediated immune escape in PDAC are regulatory T cells (Tregs). Tregs secrete immune suppressive molecules like IL-10 and TGF- $\beta$ and, therefore, their presence has generally been considered as an unfavorable prognostic factor [41, 48, 49]. However, their presence in relation to clinical outcome, as well as their immunomodulatory function in PDAC and other gastrointestinal malignancies, is still not yet fully defined. Depletion of Tregs in a preclinical PDAC model failed to relieve immunosuppression and led to accelerated tumor progression [50]. Furthermore, a systematic analysis has shown that Treg presence does not impose a negative impact on the survival of PDAC patients [51]. Myeloid cells are abundant in the PDAC tumor microenvironment and include tumor-associated macrophages and myeloidderived suppressor cells. Tumor-associated macrophages form a highly complex and heterogeneous subset of cells that can exhibit both pro-tumorigenic as anti-tumorigenic features. In cancer, macrophages can be classified according to either their phenotype or ontogeny [52]. Phenotypically, tumor-associated macrophages are divided into M1-, classically activated, macrophages that mediate tumor regression and are associated with prolonged patient survival or M2-, alternatively activated, macrophages that support tumor outgrowth and are associated with a decreased survival. Not surprisingly, M2-macrophages are the dominant subtype in the PDAC tumor microenvironment [43, 53]. Tumor-associated macrophages defined by their ontogeny can either be monocyte/ haemopoietic stem cell derived or embryonic progenitor derived [54]. In PDAC, monocyte-derived tumor-associated macrophages play a more prominent role in antigen presentation, whilst embryonically derived tumor-associated macrophages, the most frequent subtype, exhibit a pro-fibrotic transcriptional profile and support tumor progression [55]. Interestingly, the subtyping based on ontogeny has led to the discovery of CSFR1 and CXCR4 as potential immunotherapeutic targets to specifically deal with embryonic progenitor-derived tumor-associated macrophages [56, 57]. Myeloid-derived suppressor cells (MDSCs) form another heterogeneous population of (immature) myeloid cells that can also be subdivided into two main subsets: a monocytic subset and a granulocytic subset, the latter being most prominent in the PDAC tumor microenvironment [58]. Both subsets of myeloid-derived suppressor cells actively suppress host immunity through a variety of mechanisms, including the production of arginase and nitric oxide synthase (NOS), with the abundancy of myeloid-derived suppressor cells being linked to progressive disease $[59,60]$. In addition, myeloid-derived suppressor cells can amplify the immune suppressive activity of tumor-associated macrophages and dendritic cells via molecular cross-talk [61]. Dendritic cell activation in PDAC has, for example, been found to be inhibited by the production of nitric oxide synthase from myeloid-derived suppressor cells [62]. Dendritic cells are professional antigen presenting cells that are vital for the mounting of anti-tumor adaptive immune cell responses. During PDAC progression, tumor-derived cytokines can induce dendritic cell tolerogenic phenotypes and, thereby, lose their antigen presenting capacity curtailing the development of a competent anti-tumor immune response [63, 64].

Lastly, the large stromal compartment in PDAC consists of both cellular and non-cellular components that play pivotal roles in malignant cell growth and, possibly, in hampering drug delivery and immune cell infiltration $[65,66]$. Crosstalk between tumor cells and its microenvironment, i.e., with cancer-associated fibroblasts (CAFs), pancreatic stellate cells, and immune suppressive cells can lead to the onset of desmoplasia, a profoundly altered stroma with pronounced fibrosis and a shift in composition of the extracellular matrix.[67, 68]. The particular stromal and fibrotic character of PDAC is considered to be a major pillar that supports the aggressive nature of PDAC, including tumor cell proliferation, immune escape, angiogenesis and metastasis. Interfering with stromal accumulation may be a potential approach to improve the outcomes of other therapeutic interventions $[39,69]$.

In summary, the development of immunotherapies that are efficient for PDAC patients should account for the idiosyncrasies of this disease and consider aspects from cancer genetics, immune cell composition and the role that the stromal compartment plays in this disease.

\section{State of the art immunotherapies in pancreatic cancer}

\subsection{Immune checkpoint blockade therapies}

To date, targeting CTLA-4 and the PD-1/PD-L1 axis with immune checkpoint blockers (ICB) has, with the exception 
of patients diagnosed with mismatch repair-deficient tumors, failed to make an impact in PDAC (NCT02558894, NCT00729664, NCT00112580, NCT01295827, NCT01876511, see Table 1 for information concerning published clinical trials using immunotherapy including NCTnumbers) [17-21]. On the other hand, multiple studies have indicated that high expression of PD-1/PD-L1 or CTLA-4 in the PDAC tumor microenvironment is associated with a worse outcome, suggesting that targeting CTLA- 4 or the PD-1/PDL1 interaction may yield therapeutic benefit [70-72]. Combining immune checkpoint blockers with chemotherapy (platinum-based, anti-metabolite or anthracyclines) has led to encouraging results in several clinical studies in other cancer types and may, therefore, also constitute a viable strategy for PDAC [73-75]. DNA damaging agents can contribute to the cancer immunity cycle in several ways: they can cause immunogenic cell death and thereby increase antigen availability while supplying inflammatory signals, they can augment the activity of antigen-presenting cells and, finally, they can alleviate immunosuppression by depleting immune cell subsets such as myeloid-derived suppressor cells or Tregs [76-80]. Gemcitabine, the most commonly used chemotherapeutical compound in PDAC, has been shown to increase antigen presentation and to reprogram tumor-associated macrophages towards an inflammatory phenotype [76, 81]. Platinum-based compounds, such as oxaliplatin, mainly impair DNA synthesis which ultimately drives immunogenic cell death providing molecular signals that activate antigen presenting cells [82, 83]. Taxanes, such as nab-paclitaxel, do not appear to lead to immunogenic cell death, but their chemo-modulatory effects have been shown to enhance cytotoxic T cell-mediated tumor cell killing [84]. For PDAC, two phase I trials (NCT00556023, NCT02331251) have been conducted where gemcitabine was combined with either tremelimumab (antiCTLA-4) or pembrolizumab (anti-PD-1), and both approaches resulted in stabilization of disease for most patients, with two patients demonstrating partial responses in the tremelimumab study $[85,86]$. A subsequent phase II trial (NCT02331251), using gemcitabine with nab-paclitaxel and pembrolizumab (anti-PD-1) did, however, not meet its primary endpoint of $>15 \%$ complete response rate [87]

Radiotherapy is another widely used treatment modality. Based on (pre)clinical data, radiotherapy causes damage to both cancer cells and stromal cells and can trigger conversion of the tumor microenvironment from a "cold" to a "hot" immunological state [88-91]. In support of this, a phase I clinical melanoma trial has shown that radiotherapy can sensitize tumors to immune checkpoint therapy [92]. Clinical studies on combination strategies including radiation are rapidly progressing, with several studies also addressing abscopal effects of this treatment modality that may favor immunotherapy [93-95]. Currently, a phase II trial is ongoing with patients diagnosed with metastatic pancreatic cancer to determine the efficacy and safety of nivolumab or nivolumab plus ipilimumab administered concurrently with high dose radiotherapy (NCT02866383). Additional clinical studies are currently enrolling patients to address the most important issues of radiotherapy: dosing and timing.

\subsection{Vaccination strategies}

Cancer vaccines have successfully been introduced as therapeutic measures for prostate cancer, cervical cancer and premalignant vulvar intraepithelial neoplasia [96-98]. In PDAC, the development of an immunotherapeutic vaccine is faced with the challenge of identification of a suitable cancer antigen, taking into account both its specificity for the malignant tissue and its immunogenic potential [99]. To date, different vaccination strategies have been exploited for cancer treatment: heterologous whole-cell vaccines, autologous cellular vaccines and antigen-based vaccines (DNA-, RNA- or protein-based).

The most extensively clinically tested cancer vaccine in PDAC is GVAX, a heterologous whole-cell vaccine composed of two irradiated allogeneic PDAC cell lines modified to secrete GM-CSF [100]. The rationale behind this vaccine is that the cell lines that constitute the vaccine provide a representative source of PDAC antigens, eliminating the need for personalized approaches. The inclusion of GM-CSF is aimed at inducing the recruitment of immune cells, including effector $\mathrm{T}$ cells $[101,102]$. In a phase II study (NCT00084383), 60 patients treated with adjuvant chemotherapy in combination with GVAX showed 17.3 months disease-free survival and 24.8 months overall survival [103]. Although there was no significant survival benefit compared to surgery followed by chemoradiation (median survival 20.3 months), GVAX induced the expansion of mesothelin-specific CD8+ T cells. Mesothelin is considered to be an attractive tumor antigen in that it has a very limited expression profile in healthy tissues, with the exception of cells lining pleura, peritoneum and pericardium, but a high expression in PDAC cells. Furthermore, mesothelin is thought to be involved in PDAC progression and metastasis [104, 105]. Subsequently, CRS207, a liveattenuated listeria vaccine engineered to express mesothelin was added to GVAX and showed promise in a metastatic setting when compared to GVAX alone (6.1 vs 3.9 months overall survival) (NCT01417000) [106]. Unfortunately a phase II trial (NCT02004262) did not reveal a superior effect of CRS207-GVAX vaccination compared to chemotherapy [107]. In spite of both phase II trials failing to show superior effects compared to standard chemotherapeutic therapies, the GVAX vaccination did induce an adaptive immune response against PDAC, thereby demonstrating a potential to convert a non-immunogenic tumor microenvironment into an immunogenic one, and putatively turning PDAC patients into better candidates for immune checkpoint blockade therapy. In line 
Table 1 Published clinical trials using (combinatorial) immunotherapy in PDAC patients

\begin{tabular}{|c|c|c|c|}
\hline Author & Type of immunotherapy & Phase trial & NTC-numbers \\
\hline & $\begin{array}{l}\text { Checkpoint blockade as monotherapy or double therapy with or } \\
\text { without chemo- or radiotherapy }\end{array}$ & & \\
\hline O'Reilly et al. [17] & anti-PD-1 (Durvalumab) \pm anti-CTLA-4 (Tremelimumab) & II & NCT02558894 \\
\hline Brahmer et al. [18] & anti-PD-L1 & I & NCT00729664 \\
\hline Royal et al. [19] & anti-CTLA-4 (Ipilimumab) & II & NCT00112580 \\
\hline Patnaik et al. [20] & anti-PD-1 (Pembrolizumab (MK-3475)) & I & NCT01295827 \\
\hline Le et al. [21] & anti-PD-1 & II & NCT01876511 \\
\hline Aglietta et al. [85] & anti-CTLA-4 (Tremelimumab $($ CP-675,206)) \pm gemcitabine & $\mathrm{I}$ & NCT00556023 \\
\hline Weiss et al. $[86]$ & $\begin{array}{l}\text { anti-PD-1 (Pembrolizumab) + Gemcitabine ( } \pm \text { Docetaxel or nab-Paclitaxel } \\
\text { or Vinorelbine or Irinotecan or Liposomal Doxorubicin) }\end{array}$ & $\mathrm{Ib}$ & NCT02331251 \\
\hline \multirow[t]{2}{*}{ Weiss et al. [87] } & anti-PD-1 (Pembrolizumab) + Gemcitabine + nab-Paclitaxel & $\mathrm{Ib} / \mathrm{II}$ & NCT02331251 \\
\hline & Cancer vaccines & & \\
\hline Lutz et al. [103] & GVAX & II & NCT00084383 \\
\hline Le et al. (2010) & GVAX + CRS207 & $\mathrm{Ib}$ & NCT01417000 \\
\hline Le et al. $[107]$ & GVAX + CRS207 & $\mathrm{IIb}$ & NCT02004262 \\
\hline Le et al. $[109]$ & anti-CTLA-4 (Ipilimumab) + GVAX & $\mathrm{Ib}$ & NCT00836407 \\
\hline Sonntag et al. [114] & Neoepitope-derived multipeptide vaccines & $\mathrm{N} / \mathrm{A}$ & \\
\hline Gjertsen et al. [116] & RAS peptide vaccination & I & CTN RAS 95002 \\
\hline Suzuki et al. [118] & KIF20A/VEGFR1/VEGFR2 peptide vaccination & II & \\
\hline Miyazawa et al. [119] & KIF20A/VEGFR1/VEGFR2 peptide vaccination & II & \\
\hline \multirow[t]{2}{*}{ Middleton et al. [112] } & Telomerase peptide vaccine GV1001 & III & ISRCTN4382138 \\
\hline & Oncolytic viruses & & \\
\hline Mulvihill et al. [128] & Adenovirus (ONYX-015) & I & \\
\hline Hecht et al. [129] & Adenovirus (ONYX-015) & $\mathrm{I} / \mathrm{II}$ & \\
\hline Nakao et al. [130] & Oncolytic virus (HF10) & I & \\
\hline \multirow[t]{2}{*}{ Hirooka et al. [131] } & Oncolytic virus (HF10) & I & \\
\hline & Adoptive T cell therapies & & \\
\hline Thistlethwaite et al. [149] & Carcinoembryonic Antigen (CEACAM5)-specific CAR T cells & I & \\
\hline \multirow[t]{2}{*}{ Beatty et al. [150] } & Mesothelin-Specific Chimeric Antigen Receptor T Cells & I & \\
\hline & CD40 antibodies & & \\
\hline Beatty et al. [158] & CD40 monoclonal antibody (CP-870,893) & I & NCT00711191 \\
\hline \multirow[t]{2}{*}{ O'Hara et al. [159] } & CD40 monoclonal antibody (APX005M) \pm anti-PD-1 (Nivolumab) & I & NCT02482168 \\
\hline & Targeting the stromal barrier & & \\
\hline Melisi et al. [168] & TGF- $\beta$ Receptor I Kinase inhibitor (Galunisertib) + anti-PD-L1 (Durvalumab) & $\mathrm{Ib}$ & NCT02734160 \\
\hline Richeldi et al. [174] & anti-Connective Tissue Growth Factor (Pamrevlumab) & II & NCT01890265 \\
\hline Hingorani et al. $[178]$ & PEGylated Recombinant Human Hyaluronidase & $\mathrm{Ib}$ & NCT01453153 \\
\hline Hingorani et al. [179] & PEGylated Recombinant Human Hyaluronidase & II & NCT01839487 \\
\hline Ramanathan et al. [180] & PEGylated Recombinant Human Hyaluronidase & $\mathrm{Ib} / \mathrm{II}$ & NCT01959139 \\
\hline
\end{tabular}

with these notions, anti-PD-1 therapy in combination with GVAX was found to improve overall survival compared to the respective monotherapies in preclinical models [108]. The PD-1 blockade enhanced the vaccine-induced anti-tumor immune responses by increasing CD $8+\mathrm{T}$ cell infiltrates and promoting tumor-specific interferon- $\gamma$ production by CD8+ $\mathrm{T}$ cells in the tumor microenvironment. The possible synergism between GVAX vaccination and immune checkpoint blockers in a clinical setting was confirmed in a phase Ib trial (NCT00836407) with patients receiving the combination of
GVAX and an anti-CTLA-4 antibody (ipilimumab). In a cohort of locally advanced or metastatic PDAC patients, the combined treatment group showed a longer overall survival (median 5.7 months) than the group treated with ipilimumab alone (3.6 months) [109]. The success of this combinatorial setting was proposed to be caused by a GVAX-induced expansion of mesothelin-specific CD8+ T cells within the tumor microenvironment, thereby enhancing the efficacy of the antiCTLA-4 antibody treatment. Several trials are currently ongoing, combining GVAX and anti-PD-1 antibody treatment 
(NCT02451982; NCT02648282). These trials are expected to provide further evidence for this combinatorial approach.

Antigen-targeted vaccination employs another strategy aimed at stimulating an immune response specifically directed against one or multiple cancer antigens. Neoantigens are considered to be truly tumor-specific, as they arise from somatic mutations in cancer cells [110]. Several neoantigens can be targeted simultaneously per patient, provided that they are expressed in cancer tissues, presented in complex with HLA molecules and, ideally, clonal [111, 112]. Although PDACs exhibit considerably less somatic variation than other immunogenic cancer types, neoantigen recognition by $\mathrm{T}$ cells has been demonstrated in PDAC patients, which would theoretically allow the development of specific immunotherapies [113]. So far, only one case report has been published on the use of neoantigen vaccination of a PDAC patient in a clinical setting. The personalized neoantigen vaccine consisted of four peptides derived from two mutated proteins (RIM1 and KIF4B) that were determined as optimal binders to the patient's HLA alleles [114]. Three of those four peptides were shown to elicit reactivity by various CD4+ T cell clones. The patient remained in complete remission for more than four years after several rounds of therapeutic vaccination combined with GM-CSF and FOLFIRINOX in parallel. This case report demonstrates the capacity of a neoantigen vaccine to produce an immune response that might contribute to a prolonged clinical remission, warranting further investigation in clinical trials of the capabilities of neo-epitopes to generate measurable neoantigen-specific CD4 and CD8 T cell responses (NCT03956056).

Antigens derived from mutations in driver genes are optimal targets for therapeutic vaccination. Mutations at driver genes are more likely to be clonal and they are often shared between patients, albeit that the number of mutations targeting driver genes is generally much lower than those targeting passenger genes in any given tumor [22]. Common mutation targets in PDAC include KRAS, TP53, SMAD4 and $C D K N 2 A$, with KRAS mutations occurring in over $90 \%$ of PDAC patients, thereby constituting an attractive target for neoantigen-based vaccines [115]. Targeting KRAS mutant protein with a single- or poly-peptide vaccine in combination with GM-CSF has been shown to induce antigen-specific $\mathrm{T}$ cell responses in a phase I/II clinical trial, but it remained unclear whether those $\mathrm{T}$ cells actually recognized and killed tumor cells [116]. Long-term follow up of 23 patients in the previous study showed long term immunological memory against the KRAS antigens and a 20\% 10-year survival rate (4/20 patients) [117]. Building on these results, a phase I study is currently recruiting PDAC patients to evaluate the safety and immune response to a pooled mutant-KRAS peptide vaccine with poly-ICLC adjuvant in combination with nivolumab and ipilimumab after adjuvant standard of care treatment (NCT04117087).
Other clinical trials with peptide-based vaccines using tumor-associated antigens have yielded mixed results. Tumor-associated antigens are not derived from mutations, but can be highly expressed in PDAC cells. A peptide cocktail vaccine, OCV-C01, containing peptides from the vascular endothelial growth factor receptor (VEGFR) 1 and VEGFR 2 proteins, both associated with neovascularization, and a kinesin-family protein (KIF20A)-derived peptide, combined with chemotherapy was tested in an adjuvant setting. This peptide cocktail vaccine showed no benefit in 1-year survival, overall survival or progression-free survival rates, but did improve disease-free survival in per-protocol analysis and led to the generation of antigen-specific cytotoxic T-cell responses in PDAC patients [118, 119]. Human telomerase reverse transcriptase catalytic subunit (hTERT) is a component of the human telomerase machinery and a rate limiting determinant of its enzymatic activity [120]. Its expression has been found to be upregulated in several cancers including PDAC. GV1001, a human telomerase reverse transcriptase catalytic subunit-derived peptide vaccine showed promising results in a phase I/II dose escalation study, demonstrating antigenspecific $\mathrm{T}$ cell responses and prolonged patient survival [121]. Unfortunately, the addition of GV1001 in combination with GM-CSF, gemcitabine and capecitabine in a phase III trial failed to improve the overall survival of PDAC patients [122].

In conclusion, PDAC cancer vaccination strategies have shown mixed clinical results. Although most cancer vaccines tested induced vaccine-specific $\mathrm{T}$ cell responses, it remains to be determined how often the targeted antigens are actually being presented by tumor cells, particularly in the context of the generation of cytotoxic $T$ cell responses. If those antigens are indeed presented, vaccination approaches could be important complements to immune checkpoint blockade therapies.

\subsection{Oncolytic viral therapies}

In recent years, there has been a renewed interest in oncolytic viral (OV) therapy as an anti-cancer treatment modality. This approach makes use of replication-competent viruses, which replicate within the host, and preferentially target and lyse tumor cells, thereby potentially inducing robust and long lasting immunity [123]. Moreover, since the first FDA-approved oncolytic viral therapy, T-VEC (Imlygic ${ }^{\mathrm{TM}}$ ), a recombinant human herpes simplex virus type 1 (HSV-1), oncolytic viruses have been engineered for optimization of tumor selectivity and enhanced immune stimulation [124]. Oncolytic viruses for the treatment of pancreatic cancer that have been tested in recent experimental and clinical studies include adenoviruses, herpesviruses and reoviruses [125]. Oncolytic adenoviruses were among the earliest to enter clinical trials. ONYX015 is an E1B 55-kDa gene-deleted adenovirus that can replicate in and lyse p53-deficient cancer cells, but not cells with 
functional p53 [126, 127]. A dose-escalation phase I study showed that intra-tumoral injection of ONYX-015 into primary pancreatic cancers was feasible and well tolerated, but without objective responses and absence of viral replication in biopsy specimens [128]. A subsequent phase II trial administrating ONYX-015 in combination with gemcitabine in unresectable primary pancreatic tumors showed partial tumor regression in two patients, whereas two patients showed minor responses, six patients showed stable disease and 11 patients showed tumor progression [129]. HF10, which is a naturally mutated virus, has a replication capacity similar to or higher than wild-type HSV-1 in most types of transformed cells. Nakao et al, performed a phase I clinical trial and treated six PDAC patients with HF10. After treatment three patients were stable, one was in regression and two showed disease progression [130]. A more recent study showed that directly injected HF10 under endoscopic ultrasound guidance in combination with erlotinib and gemcitabine administration, was safe and had an anti-tumor effect. Out of nine patients who completed the treatment, three showed partial responses, four showed stable disease and two experienced disease progression [131]. Other oncolytic viruses include wild type rat parvovirus H1 (ParvOryx) and a variant of a reovirus (Reolysin). These have been extensively tested in PDAC patients, showing good tolerability but no superior effect on survival [132-134]. To increase their anti-cancer potency, oncolytic viruses have been modified to express checkpoint inhibitory antibodies or immune stimulatory molecules, thereby directing their expression in tumor tissues whilst avoiding adverse effects resulting from the systemic delivery of immune modulators [135-138]. Despite several viruses that have been tested in PDAC, their clinical efficacy was limited. If oncolytic viral PDAC therapies are to be considered, further studies are urgently needed to enable the translation of these potentially successful therapies into clinical use.

\subsection{Adoptive T cell therapies}

Adoptive T cell therapy (ACT) involves the administration of autologous immune cells that can be enriched for tumor specificity, to cancer patients [139]. To achieve this, adoptive T cell therapy can make use of a patient's naturally occurring tumor-infiltrating lymphocytes (TILs) or tumor-specific $\mathrm{T}$ cells obtained from peripheral blood-derived lymphocytes, which can be expanded and activated ex vivo by incubation with autologous tumor material or cancer antigens [140]. A central requirement for the efficacy of this approach is the existence of cancer antigen-specific $\mathrm{T}$ cells. These are, however, often not present or difficult to isolate from most PDAC patients [141]. In the absence of naturally occurring tumorspecific $\mathrm{T}$ cells, strategies that make use of $\mathrm{T}$ cell engineering may be an alternative.
Chimeric antigen receptor (CAR) $\mathrm{T}$ cell therapy is an adoptive $\mathrm{T}$ cell strategy that makes use of $\mathrm{T}$ cells genetically engineered to express chimeric antigen receptors (CARs). CARs are composed of an extracellular, antigen-binding domain (typically corresponding to the variable regions of an antibody) and an intracellular TCR-signaling domain. Compared to T-cell receptor therapy, CAR T cells are not HLA-restricted and can potentially be engineered to recognize any target expressed on the surface of tumor cells [142]. In B cell malignancies, CAR T cell therapies have shown impressive results, as they target $\mathrm{B}$ cell lineagespecific molecules such as CD19, CD20 and CD22 that are not expressed in other tissues [143]. The effectiveness of CAR T cell therapies in solid tumors has so far been limited [144]. PDAC, like other solid tumors, does not present ideal CAR targets, as there is a paucity of cell surface tumor-specific molecules. Besides, the profound degree of immunosuppression limits both the persistence of CAR T cells and their ability to effectively traffic to tumor sites [145]. Preclinical PDAC studies using genetically engineered CARs expressing tumor-associated antigens, including CEA, Her2 and MUC-1 showed promising results [146-148]. Unfortunately, a feasibility study in patients with advanced $\mathrm{CEACAM}^{+}$malignancies, including one PDAC patient, using anti-CEA CAR T cell therapy provoked significant respiratory toxicities, resulting in premature closure of the study [149]. On the other hand, a phase I trial has been completed using CAR T cells targeting mesothelin in chemotherapy-refractory metastatic pancreatic cancer patients and showed preliminary antitumor efficacy [150]. Local administration of CAR T cells by intra-tumoral injection or the use of biopolymer scaffolds could lead to superior antitumor responses in solid tumors [151]. To augment their specificity and decrease their off-target toxicity, a new generation of CARs is under investigation where CAR $\mathrm{T}$ cells are equipped with the ability to produce immune modulatory cytokines or checkpoint inhibitors [152]. Interestingly, the addition of anti-PD-1/PD-L1, in preclinical models restored the killing capacity of CAR $T$ cells and diminished the amount of immune suppressive cells and the exhaustion of T cells $[153,154]$. A wider therapeutic application of CAR T cells in solid tumors holds promise if the delivery to tumor sites and the persistence of CAR T cells can be improved.

\subsection{CD40 agonists}

During the process of $\mathrm{T}$ cell priming, the presence of CD40 ligand (CD154), expressed by helper T cells, is essential for competent activation of dendritic cells and subsequent antigen presentation and provision of co-stimulatory signals to cytotoxic T cells [155]. CD40 agonists can, therefore, bypass the potential absence of $\mathrm{T}$ helper signaling in less immunogenic cancer types such as PDAC and license antigen presenting cells to promote T cell activation [156]. Preclinical testing of a CD40 agonist together with gemcitabine significantly reduced PDAC tumor burden and improved survival in mice, 
compared to monotherapy with either drug [157]. A phase I clinical trial (NCT00711191) using CD40 agonist monoclonal antibody therapy in combination with gemcitabine showed an objective response of $19 \%$ in patients with advanced PDAC, with immune activation [158]. A subsequent phase Ib trial (NCT02482168) with metastatic pancreatic cancer patients treated with chemotherapy and a CD40 agonist with or without an anti-PD1 antibody (nivolumab) showed promise with definitive results expected soon [159].

\section{Targeting the stromal barrier to guide immunotherapy}

An avenue worth pursuing to improve the success of immunotherapy in PDAC patients is the breaking down of the stromal desmoplastic barrier and the targeting of cancerassociated fibroblasts. High desmoplasia with low vascular perfusion potentially impedes the delivery of drugs as well as immune cell infiltration. Furthermore, it contributes to a hypoxic environment which, in turn, promotes the accumulation of immunosuppressive cells and aggressive features of tumor cells [23]. Several molecules are involved in the buildup and maintenance of a pronounced PDAC stromal component and, if targetable, they may sensitize PDAC to other treatment regimens, including immunotherapy.

\subsection{Focal adhesion kinase (FAK)}

Focal adhesion kinase (FAK), a non-receptor protein tyrosine kinase, is a mechano-sensor that is crucial for crosstalk between different components of the extracellular matrix and is expressed by almost all tissues and cell types $[160,161]$. In PDAC patients, FAK is activated and overexpressed in the neoplastic cells and, to a lesser extent, in the stromal cells within the tumor microenvironment. Its expression is associated with a poor prognosis [162]. Preclinical testing of FAK inhibition resulted in reduced fibrosis in tumors and a decreased proliferation of cancer cells [163]. Intriguingly, additional preclinical work using FAK inhibition in combination with PD-1 blockade revealed increased amounts of tumorinfiltrating cytotoxic $\mathrm{T}$ cells, reductions in tumor burden and an improved survival [162]. Currently, two phase II clinical trials are ongoing enrolling pancreatic and other solid cancer patients receiving Defactinib (Verastem Oncology) in combination with an anti-PD-1 monoclonal antibody (Pembrolizumab) (NCT02758587, NCT03727880).

\subsection{Transforming growth factor $\beta$ (TGF- $\beta$ )}

Transforming growth factor $\beta$, with its different isoforms, $T G F B 1, T G F B 2$ and $T G F B 3$, represents a family of cytokines that are ubiquitously expressed during tumorigenesis and have pleiotropic effects $[164,165]$. In the desmoplastic stromal reaction of PDAC, TGF- $\beta$ signaling, specifically TGF $\beta$ receptor I (TGF $\beta R I$ ), acts as an activator of pancreatic stellate cells and induces/maintains its own expression through a positive feedback loop, thereby supporting fibrosis and immune evasion [166]. A preclinical co-culture model using Galunisertib (LY2157299 monohydrate), an oral small molecule inhibitor of the chimeric TGFßRI-ALK5 kinase, revealed that this feedback loop can be blocked [167]. Subsequent clinical testing in a PDAC phase $\mathrm{Ib}$ trial, comparing Galunisertib in combination with gemcitabine versus gemcitabine alone, showed marginal results with an improved overall survival in the Galunisertib cohort (8.9 vs 7.1 months) [168]. A phase Ib trial (NCT02734160) looking into the synergy of Galunsertib and an anti-PD-L1 inhibitor (Durvalumab) resulted in one partial response and 7 out of 32 patient showing stable disease (disease control rate 25\%), warranting further consideration for PDAC patients [169].

\subsection{Connective tissue growth factor}

Connective tissue growth factor $(\mathrm{CTGF} / \mathrm{CCN} 2)$ is a member of the CCN family of proteins and is involved in extracellular matrix production, desmoplasia, tumor cell proliferation, adhesion, migration, angiogenesis and metastasis [170]. CTGF is overexpressed in human pancreatic cancer due to activation of the RAS/MAP-ERK pathway, which occurs in the vast majority of PDACs $[171,172]$. Using a mouse model, inhibition of CTGF was shown to decrease tumor growth without attenuation of the chemotherapeutic effects of gemcitabine [173]. Pamrevlumab (Fibrogen), an anti-CTGF therapeutic, was tested in a phase II trial (NCT01890265) in patients with idiopathic pulmonary fibrosis, another disease exhibiting CTGF overexpression [174]. After showing promising results, a phase III study is now ongoing also enrolling pancreatic cancer patients (NCT03941093).

\subsection{PEGylated human recombinant hyaluronidase}

Hyaluronic acid (HA) is another potential target within the pancreatic cancer stroma. Hyaluronic acid is a hydrophilic glycosaminoglycan whose production leads to increased interstitial tumor pressure, thereby limiting the access of potentially effective circulating anticancer drugs via reduced tumor perfusion [175]. In a retrospective analysis, pancreatic cancer patients with a high hyaluronic acid accumulation exhibited a median overall survival of 9.3 months, compared with 24.3 months for those with a low accumulation [176]. In a preclinical PDAC model, enzymatic depletion of HA resulted in increased tumor perfusion allowing other chemotherapeutic drugs to penetrate the tumor microenvironment, thereby decreasing the tumor burden and improving survival [177]. A subsequent phase $\mathrm{Ib} / \mathrm{II}$ multicenter randomized placebo- 
Table 2 Notable ongoing clinical trials using (combinatorial) immunotherapy in PDAC patients

\begin{tabular}{|c|c|c|}
\hline Type of immunotherapy & Phase trial & NTC-numbers \\
\hline Gemcitabine + Nab-paclitaxel + CD40-agonist $($ APX005M) +/- anti-PD-1 (Nivolumab) & $\mathrm{Ib} / \mathrm{II}$ & NCT03214250 \\
\hline Anti-PD-1 (Pembrolizumab) + CD40-agonist (CDX-1140) + FLT3 Ligand (CDX-301) & I & NCT03329950 \\
\hline Radiotherapy + anti-CTLA-4 (Ipilimumab) + anti-PD-1 (Nivolumab) & I & NCT02866383 \\
\hline SBRT + Anti-PD-1 (Nivolumab) + anti-CSF1R (Cabiralizumab) & II & NCT03599362 \\
\hline SBRT + anti-CTLA-4 (Tremelimumab) + anti-PD-1 (Durvalumab) & $\mathrm{I} / \mathrm{II}$ & NCT02311361 \\
\hline SBRT + GVAX + anti-PD-1 (Nivolumab) + anti-CCR2/CCR5 & $\mathrm{I} / \mathrm{II}$ & NCT03767582 \\
\hline Cyclophosphamide + GVAX +/- anti-PD-1 (Nivolumab) + anti-CD137 (Urelumab) & $\mathrm{I} / \mathrm{II}$ & NCT02451982 \\
\hline Cyclophosphamide + GVAX + anti-PD-1 (Pembrolizumab) + SBRT & II & NCT02648282 \\
\hline Cyclophosphamide + GVAX + anti-PD-1 (Pembrolizumab) + anti-CSF1R (IMC-CS4) & I & NCT03153410 \\
\hline MultiTAA specific T cells (TAA-CTLs) & I & NCT03192462 \\
\hline Neoantigen peptide vaccine + Poly ICLC & I & NCT03956056 \\
\hline KRAS peptide vaccine + poly ICLC + anti-PD-1 (Nivolumab) + anti-CTLA4 (Ipilimumab) & I & NCT04117087 \\
\hline huCART-meso cells & I & NCT03323944 \\
\hline anti-MUC1 CAR T cells & $\mathrm{I} / \mathrm{II}$ & NCT02587689 \\
\hline Gemcitabine + Nab-paclitaxel +/- anti-CTGF (Pamrevlumab) & III & NCT03941093 \\
\hline Gemcitabine + anti-PD-1 (Pembrolizumab) + FAK-inhibitor (Defactinib) & I & NCT02546531 \\
\hline FAK-inihbitor (Defactinib) + anti-PD-1 (Pembrolizumab) & $\mathrm{I} / \mathrm{II}$ & NCT02758587 \\
\hline Anti-PD-1 (Pembrolizumab) + FAK-inhibitor (Defactinib) & II & NCT03727880 \\
\hline PEGylated Recombinant Human Hyaluronidase (PEGPH20) + anti-PD-1 (Pembrolizumab) & II & NCT03634332 \\
\hline PEGylated Recombinant Human Hyaluronidase (PEGPH20) + Gemcitabine + Nab-paclitaxel & N/A & NCT02921022 \\
\hline
\end{tabular}

controlled study (NCT01453153) was conducted evaluating PEGPH20 combined with gemcitabine in patients with previously untreated stage IV PDAC [178]. The addition of PEGPH20 to gemcitabine was especially beneficial in patients with HA-high tumors, showing higher response and longer progression-free survival rates. To improve the chemosensitivity of the PDAC patients, two subsequent trials (NCT01839487, NCT01959139) tested the combination of PEGPH20 with gemcitabine and nab-paclitaxel [179] or FOLFIRINOX [180]. Interestingly, the phase II trial using gemcitabine plus nab-paclitaxel chemotherapy showed an improvement in progression free survival when PEGPH20 was added to HA-high tumors [179]. The addition of PEGPH20 to FOLFIRINOX had, however, a detrimental effect in PDAC patients [180]. Several clinical trials are currently ongoing, combining PEGPH20 with chemotherapy, checkpoint blockade therapy, radiation therapy and rivaroxaban in patients with stage IV pancreatic cancer.

\section{Conclusions and perspectives}

Immunotherapy for advanced PDAC desperately needs a breakthrough. To maximize success rates of immunotherapy in an era of personalized medicine, molecular and immune profiling should be the starting points of treatment selection. Recent classifications of PDAC on the basis of molecular subtypes related to immunogenicity could aid in immunotherapeutic treatment selection, although its clinical implementation still needs to be validated [37]. Emerging genomic and other biomarker profiles have provided unprecedented opportunities to identify novel targets and strategies establish personalized therapeutic approaches. The advent of multidimensional single-cell technologies that include spatial information will shed light on the tremendous cellular diversity that exists within PDACs as well as heterogeneity across PDAC patients. Novel (checkpoint) targets, such as VISTA, CSFR-1 and CCR5, have already been identified, and some of them are currently being tested in a clinical setting [44]. Although novel (checkpoint) targets are anticipated, we should first build upon what has already been shown in clinical settings. For PDAC, it seems to be particularly important to provide an inflammatory trigger that initiates, or re-initiates, anti-tumor responses. New treatment strategies should incorporate an immune stimulatory approach before making use of conventional/novel checkpoint blockade therapies. Of note, advances in the identification and targeting of neoantigens may become a safe and effective way to trigger anti-tumor immune responses [181, 182]. Currently, other agents that stimulate $\mathrm{T}$ cell activation and priming, CD40 agonists in particular, seem most promising in providing an immune trigger in PDAC patients. Its putative synergy with checkpoint blockade therapy is currently being tested and will hopefully hold future promise (see Table 2 for noteworthy trials). In addition, it may be 
particularly important, and useful, to target specific components of the stromal compartment in PDAC, thereby facilitating the infiltration of immune cells as well as other therapeutic agents. Pamrevlumab (Fibrogen), an anti-CTGF therapy, has already moved to phase III testing and, as such, may provide a new window of opportunityr not only for immunotherapy but also for conventional chemotherapies.

In short, the successful use of immunotherapy in PDAC patients remains an uphill battle. The research field should make optimal use of system-wide approaches integrating the different idiosyncrasies of the PDAC tumor microenvironment. Once immunotherapy is apt for PDAC patients, we believe that combinatorial treatment strategies will herald a new spark of light at the end of a long tunnel.

Acknowledgements This work was supported by the European Commission H2020 MSCA-ETN grant under proposal number 675743 (project acronym: ISPIC) and the European Research Council (ERC) under the European Union's Horizon 2020 research and innovation programme (grant agreement No. 852832)

Author contributions All authors contributed to the manuscript conception and design. TB performed the literature search, data analysis and wrote the first draft of the manuscript. NdM and AV critically revised the manuscript. All authors read and approved the final manuscript.

\section{Declaration}

Conflict of Interest The authors declare that they have no conflict of interest.

Open Access This article is licensed under a Creative Commons Attribution 4.0 International License, which permits use, sharing, adaptation, distribution and reproduction in any medium or format, as long as you give appropriate credit to the original author(s) and the source, provide a link to the Creative Commons licence, and indicate if changes were made. The images or other third party material in this article are included in the article's Creative Commons licence, unless indicated otherwise in a credit line to the material. If material is not included in the article's Creative Commons licence and your intended use is not permitted by statutory regulation or exceeds the permitted use, you will need to obtain permission directly from the copyright holder. To view a copy of this licence, visit http://creativecommons.org/licenses/by/4.0/.

\section{References}

1. L. Rahib, B.D. Smith, R. Aizenberg, A.B. Rosenzweig, J.M. Fleshman, L.M. Matrisian, Projecting cancer incidence and deaths to 2030: the unexpected burden of thyroid, liver, and pancreas cancers in the United States. Cancer Res. 74, 2913-2921 (2014)

2. F. Bray, J. Ferlay, I. Soerjomataram, R.L. Siegel, L.A. Torre, A. Jemal, Global cancer statistics 2018: GLOBOCAN estimates of incidence and mortality worldwide for 36 cancers in 185 countries. CA Cancer J. Clin. 68, 394-424 (2018)

3. P. Rawla, T. Sunkara, V. Gaduputi, Epidemiology of pancreatic cancer: Global trends. etiology and risk factors. World J. Oncol. 10, 10-27 (2019)
4. T. Kamisawa, L.D. Wood, T. Itoi, K. Takaori, Pancreatic cancer. Lancet 388, 73-85 (2016)

5. H. Oettle, P. Neuhaus, A. Hochhaus, J.T. Hartmann, K. Gellert, K. Ridwelski, M. Niedergethmann, C. Zulke, J. Fahlke, M.B. Arning, M. Sinn, A. Hinke, H. Riess, Adjuvant chemotherapy with gemcitabine and long-term outcomes among patients with resected pancreatic cancer: the CONKO-001 randomized trial. JAMA 310, 1473-1481 (2013)

6. J.P. Neoptolemos, D.H. Palmer, P. Ghaneh, E.E. Psarelli, J.W. Valle, C.M. Halloran, O. Faluyi, D.A. O'Reilly, D. Cunningham, J. Wadsley, S. Darby, T. Meyer, R. Gillmore, A. Anthoney, P. Lind, B. Glimelius, S. Falk, J.R. Izbicki, G.W. Middleton, S. Cummins, P.J. Ross, H. Wasan, A. McDonald, T. Crosby, Y.T. Ma, K. Patel, D. Sherriff, R. Soomal, D. Borg, S. Sothi, P. Hammel, T. Hackert, R. Jackson, M.W. Buchler, Comparison of adjuvant gemcitabine and capecitabine with gemcitabine monotherapy in patients with resected pancreatic cancer (ESPAC-4): a multicentre, open-label, randomised, phase 3 trial. Lancet $\mathbf{3 8 9}$, 1011-1024 (2017)

7. D.D. Von Hoff, T. Ervin, F.P. Arena, E.G. Chiorean, J. Infante, M. Moore, T. Seay, S.A. Tjulandin, W.W. Ma, M.N. Saleh, M. Harris, M. Reni, S. Dowden, D. Laheru, N. Bahary, R.K. Ramanathan, J. Tabernero, M. Hidalgo, D. Goldstein, E. Van Cutsem, X. Wei, J. Iglesias, M.F. Renschler, Increased survival in pancreatic cancer with nab-paclitaxel plus gemcitabine. N. Engl. J. Med. 369, 1691-1703 (2013)

8. T. Conroy, P. Hammel, M. Hebbar, M.B. Abdelghani, A.C. Wei, J.L. Raoul, L. Chone, E. Francois, P. Artru, J.J. Biagi, T. Lecomte, E. Assenat, R. Faroux, M. Ychou, J. Volet, A. Sauvanet, G. Breysacher, F. Di Fiore, C. Cripps, P. Kavan, P. Texereau, K. Bouhier-Leporrier, F. Khemissa-Akouz, J.L. Legoux, B. Juzyna, S. Gourgou, C.J. O'Callaghan, C. Jouffroy-Zeller, P. Rat, D. Malka, F. Castan, J.B. Bachet, G. Canadian cancer trials and G.I.P.G. the unicancer, FOLFIRINOX or gemcitabine as adjuvant therapy for pancreatic cancer. N. Engl. J. Med. 379, 2395-2406 (2018)

9. T. Hackert, M. Sachsenmaier, U. Hinz, L. Schneider, C.W. Michalski, C. Springfeld, O. Strobel, D. Jager, A. Ulrich, M.W. Buchler, Locally advanced pancreatic cancer: Neoadjuvant therapy with folfirinox results in resectability in $60 \%$ of the patients. Ann. Surg. 264, 457-463 (2016)

10. S.J. Antonia, H. Borghaei, S.S. Ramalingam, L. Horn, J. De Castro Carpeno, A. Pluzanski, M.A. Burgio, M. Garassino, L.Q.M. Chow, S. Gettinger, L. Crino, D. Planchard, C. Butts, A. Drilon, J. Wojcik-Tomaszewska, G.A. Otterson, S. Agrawal, A. Li, J.R. Penrod, J. Brahmer, Four-year survival with nivolumab in patients with previously treated advanced non-small-cell lung cancer: a pooled analysis. The Lancet. Oncology 20, 1395-1408 (2019)

11. D. Schadendorf, F.S. Hodi, C. Robert, J.S. Weber, K. Margolin, O. Hamid, D. Patt, T.T. Chen, D.M. Berman, J.D. Wolchok, Pooled analysis of long-term survival data from phase II and phase III trials of Ipilimumab in unresectable or metastatic melanoma. J. Clin. Oncol. 33, 1889-1894 (2015)

12. J. von Pawel, R. Bordoni, M. Satouchi, L. Fehrenbacher, M. Cobo, J.Y. Han, T. Hida, D. Moro-Sibilot, P. Conkling, D.R. Gandara, A. Rittmeyer, M. Gandhi, W. Yu, C. Matheny, H. Patel, A. Sandler, M. Ballinger, M. Kowanetz, K. Park, Longterm survival in patients with advanced non-small-cell lung cancer treated with atezolizumab versus docetaxel: Results from the randomised phase III OAK study. Eur. J. Cancer 107, 124-132 (2019)

13. P.C. Tumeh, C.L. Harview, J.H. Yearley, I.P. Shintaku, E.J. Taylor, L. Robert, B. Chmielowski, M. Spasic, G. Henry, V. Ciobanu, A.N. West, M. Carmona, C. Kivork, E. Seja, G. Cherry, A.J. Gutierrez, T.R. Grogan, C. Mateus, G. Tomasic, 
J.A. Glaspy, R.O. Emerson, H. Robins, R.H. Pierce, D.A. Elashoff, C. Robert, A. Ribas, PD-1 blockade induces responses by inhibiting adaptive immune resistance. Nature 515, 568-571 (2014)

14. A. Snyder, V. Makarov, T. Merghoub, J. Yuan, J.M. Zaretsky, A. Desrichard, L.A. Walsh, M.A. Postow, P. Wong, T.S. Ho, T.J. Hollmann, C. Bruggeman, K. Kannan, Y. Li, C. Elipenahli, C. Liu, C.T. Harbison, L. Wang, A. Ribas, J.D. Wolchok, T.A. Chan, Genetic basis for clinical response to CTLA-4 blockade in elanoma. N. Engl. J. Med. 2189-2199 (2014)

15. N.A. Rizvi, M.D. Hellmann, A. Snyder, P. Kvistborg, V. Makarov, J.J. Havel, W. Lee, J. Yuan, P. Wong, T.S. Ho, M.L. Miller, N. Rekhtman, A.L. Moreira, F. Ibrahim, C. Bruggeman, B. Gasmi, R. Zappasodi, Y. Maeda, C. Sander, E.B. Garon, T. Merghoub, J.D. Wolchok, T.N. Schumacher, T.A. Chan, Cancer immunology. Mutational landscape determines sensitivity to PD1 blockade in non-small cell lung cancer. Science 348, 124-128 (2015)

16. R.S. Herbst, J.C. Soria, M. Kowanetz, G.D. Fine, O. Hamid, M.S. Gordon, J.A. Sosman, D.F. McDermott, J.D. Powderly, S.N. Gettinger, H.E. Kohrt, L. Horn, D.P. Lawrence, S. Rost, M. Leabman, Y. Xiao, A. Mokatrin, H. Koeppen, P.S. Hegde, I. Mellman, D.S. Chen, F.S. Hodi, Predictive correlates of response to the anti-PD-L1 antibody MPDL3280A in cancer patients. Nature 515, 563-567 (2014)

17. E.M. O'Reilly, D.Y. Oh, N. Dhani, D.J. Renouf, M.A. Lee, W. Sun, G. Fisher, A. Hezel, S.C. Chang, G. Vlahovic, O. Takahashi, Y. Yang, D. Fitts, P.A. Philip, Durvalumab with or without Tremelimumab for patients with metastatic pancreatic ductal adenocarcinoma: A phase 2 randomized clinical trial. JAMA Oncol. 5, 1431-1438 (2019)

18. J.R. Brahmer, S.S. Tykodi, L.Q.M. Chow, W.-J. Hwu, S.L. Topalian, P. Hwu, C.G. Drake, L.H. Camacho, J. Kauh, K. Odunsi, H.C. Pitot, O. Hamid, S. Bhatia, R. Martins, K. Eaton, S. Chen, T.M. Salay, S. Alaparthy, J.F. Grosso, A.J. Korman, S.M. Parker, S. Agrawal, S.M. Goldberg, D.M. Pardoll, A. Gupta, J.M. Wigginton, Safety and activity of anti-PD-L1 antibody in patients with advanced cancer. N. Engl. J. Med. 366, 2455-2465 (2012)

19. R.E. Royal, C. Levy, K. Turner, A. Mathur, M. Hughes, U.S. Kammula, R.M. Sherry, S.L. Topalian, J.C. Yang, I. Lowy, S.A. Rosenberg, Phase 2 trial of single agent Ipilimumab (anti-CTLA4) for locally advanced or metastatic pancreatic adenocarcinoma. J. Immunother. 33, 828-833 (2010)

20. A. Patnaik, S.P. Kang, D. Rasco, K.P. Papadopoulos, J. ElassaissSchaap, M. Beeram, R. Drengler, C. Chen, L. Smith, G. Espino, K. Gergich, L. Delgado, A. Daud, J.A. Lindia, X.N. Li, R.H. Pierce, J.H. Yearley, D. Wu, O. Laterza, M. Lehnert, R. Iannone, A.W. Tolcher, Phase I study of Pembrolizumab (MK3475; anti-PD-1 monoclonal antibody) in patients with advanced solid tumors. Clin. Cancer Res. 21, 4286-4293 (2015)

21. D.T. Le, J.N. Durham, K.N. Smith, H. Wang, B.R. Bartlett, L.K. Aulakh, S. Lu, H. Kemberling, C. Wilt, B.S. Luber, F. Wong, N.S. Azad, A.A. Rucki, D. Laheru, R. Donehower, A. Zaheer, G.A. Fisher, T.S. Crocenzi, J.J. Lee, T.F. Greten, A.G. Duffy, K.K. Ciombor, A.D. Eyring, B.H. Lam, A. Joe, S.P. Kang, M. Holdhoff, L. Danilova, L. Cope, C. Meyer, S. Zhou, R.M. Goldberg, D.K. Armstrong, K.M. Bever, A.N. Fader, J. Taube, F. Housseau, D. Spetzler, N. Xiao, D.M. Pardoll, N. Papadopoulos, K.W. Kinzler, J.R. Eshleman, B. Vogelstein, R.A. Anders, L.A. Diaz Jr., Mismatch repair deficiency predicts response of solid tumors to PD-1 blockade. Science 357, 409-413 (2017)

22. R. Moncada, D. Barkley, F. Wagner, M. Chiodin, J.C. Devlin, M. Baron, C.H. Hajdu, D.M. Simeone, I. Yanai, Integrating microarray-based spatial transcriptomics and single-cell RNA- seq reveals tissue architecture in pancreatic ductal adenocarcinomas. Nat. Biotechnol. 38, 333-342 (2020)

23. D.P. Ryan, T.S. Hong, N. Bardeesy, Pancreaticadenocarcinoma. N. Engl. J. Med. 371, 1039-1049 (2014)

24. C. Feig, A. Gopinathan, A. Neesse, D.S. Chan, N. Cook, D.A. Tuveson, The pancreas cancer microenvironment. Clin. Cancer Res. 18, 4266-4276 (2012)

25. R. Moncada, D. Barkley, F. Wagner, M. Chiodin, J.C. Devlin, M. Baron, C.H. Hajdu, D.M. Simeone, I. Yanai, Integrating microarray-based spatial transcriptomics and single-cell RNA-seq reveals tissue architecture in pancreatic ductal adenocarcinomas. Nat. Biotechnol. 38, 333-342 (2020)

26. E. Elyada, M. Bolisetty, P. Laise, W.F. Flynn, E.T. Courtois, R.A. Burkhart, J.A. Teinor, P. Belleau, G. Biffi, M.S. Lucito, S. Sivajothi, T.D. Armstrong, D.D. Engle, K.H. Yu, Y. Hao, C.L. Wolfgang, Y. Park, J. Preall, E.M. Jaffee, A. Califano, P. Robson, D.A. Tuveson, Cross-species single-cell analysis of pancreatic ductal adenocarcinoma reveals antigen-presenting cancer-associated fibroblasts. Cancer Discov. 9, 1102-1123 (2019)

27. L.B. Alexandrov, S.A. Nik-zainal, D.C. Wedge, S.A.J.R. Aparicio, S. Behjati, A.V. Biankin, G.R. Bignelli, N. Bolli, A. Borg, A.-L. Borresen-Dale, N. Waddell, L.R. Yates, Signatures of mutational processes in human cancer. Nature 500, 415-425 (2013)

28. M. Erkan, C.W. Michalski, S. Rieder, C. Reiser-Erkan, I. Abiatari, A. Kolb, N.A. Giese, I. Esposito, H. Friess, J. Kleeff, The activated stroma index is a novel and independent prognostic marker in pancreatic ductal adenocarcinoma. Clin. Gastroenterol. Hepatol. 6, 1155-1161 (2008)

29. S. Jones, X. Zhang, D.W. Parsons, J.C. Lin, R.J. Leary, P. Angenendt, P. Mankoo, H. Carter, H. Kamiyama, A. Jimeno, S.M. Hong, B. Fu, M.T. Lin, E.S. Calhoun, M. Kamiyama, K. Walter, T. Nikolskaya, Y. Nikolsky, J. Hartigan, D.R. Smith, M. Hidalgo, S.D. Leach, A.P. Klein, E.M. Jaffee, M. Goggins, A. Maitra, C. Iacobuzio-Donahue, J.R. Eshleman, S.E. Kern, R.H. Hruban, R. Karchin, N. Papadopoulos, G. Parmigiani, B. Vogelstein, V.E. Velculescu, K.W. Kinzler, Core signaling pathways in human pancreatic cancers revealed by global genomic analyses. Science 321, 1801-1806 (2008)

30. A.V. Biankin, N. Waddell, K.S. Kassahn, M.C. Gingras, L.B. Muthuswamy, A.L. Johns, D.K. Miller, P.J. Wilson, A.M. Patch, J. Wu, D.K. Chang, M.J. Cowley, B.B. Gardiner, S. Song, I. Harliwong, S. Idrisoglu, C. Nourse, E. Nourbakhsh, S. Manning, S. Wani, M. Gongora, M. Pajic, C.J. Scarlett, A.J. Gill, A.V. Pinho, I. Rooman, M. Anderson, O. Holmes, C. Leonard, D. Taylor, S. Wood, Q. Xu, K. Nones, J.L. Fink, A. Christ, T. Bruxner, N. Cloonan, G. Kolle, F. Newell, M. Pinese, R.S. Mead, J.L. Humphris, W. Kaplan, M.D. Jones, E.K. Colvin, A.M. Nagrial, E.S. Humphrey, A. Chou, V.T. Chin, L.A. Chantrill, A. Mawson, J.S. Samra, J.G. Kench, J.A. Lovell, R.J. Daly, N.D. Merrett, C. Toon, K. Epari, N.Q. Nguyen, A. Barbour, N. Zeps, I.A.P.C. Genome, N. Kakkar, F. Zhao, Y.Q. Wu, M. Wang, D.M. Muzny, W.E. Fisher, F.C. Brunicardi, S.E. Hodges, J.G. Reid, J. Drummond, K. Chang, Y. Han, L.R. Lewis, H. Dinh, C.J. Buhay, T. Beck, L. Timms, M. Sam, K. Begley, A. Brown, D. Pai, A. Panchal, N. Buchner, R. De Borja, R.E. Denroche, C.K. Yung, S. Serra, N. Onetto, D. Mukhopadhyay, M.S. Tsao, P.A. Shaw, G.M. Petersen, S. Gallinger, R.H. Hruban, A. Maitra, C.A. Iacobuzio-Donahue, R.D. Schulick, C.L. Wolfgang, R.A. Morgan, R.T. Lawlor, P. Capelli, V. Corbo, M. Scardoni, G. Tortora, M.A. Tempero, K.M. Mann, N.A. Jenkins, P.A. PerezMancera, D.J. Adams, D.A. Largaespada, L.F. Wessels, A.G. Rust, L.D. Stein, D.A. Tuveson, N.G. Copeland, E.A. Musgrove, A. Scarpa, J.R. Eshleman, T.J. Hudson, R.L. Sutherland, D.A. Wheeler, J.V. Pearson, J.D. McPherson, R.A. Gibbs, S.M. Grimmond, Pancreatic cancer genomes reveal 
aberrations in axon guidance pathway genes. Nature 491, 399405 (2012)

31. A.K. Witkiewicz, E.A. McMillan, U. Balaji, G. Baek, W.C. Lin, J. Mansour, M. Mollaee, K.U. Wagner, P. Koduru, A. Yopp, M.A. Choti, C.J. Yeo, P. McCue, M.A. White, E.S. Knudsen, Wholeexome sequencing of pancreatic cancer defines genetic diversity and therapeutic targets. Nat. Commun. 6, 6744 (2015)

32. J.L. Humphris, A.-M. Patch, K. Nones, P.J. Bailey, A.L. Johns, S. McKay, D.K. Chang, D.K. Miller, M. Pajic, K.S. Kassahn, M.C.J. Quinn, T.J.C. Bruxner, A.N. Christ, I. Harliwong, S. Idrisoglu, S. Manning, C. Nourse, E. Nourbakhsh, A. Stone, P.J. Wilson, M. Anderson, J.L. Fink, O. Holmes, S. Kazakoff, C. Leonard, F. Newell, N. Waddell, S. Wood, R.S. Mead, Q. Xu, J. Wu, M. Pinese, M.J. Cowley, M.D. Jones, A.M. Nagrial, V.T. Chin, L.A. Chantrill, A. Mawson, A. Chou, C.J. Scarlett, A.V. Pinho, I. Rooman, M. Giry-Laterriere, J.S. Samra, J.G. Kench, N.D. Merrett, C.W. Toon, K. Epari, N.Q. Nguyen, A. Barbour, N. Zeps, N.B. Jamieson, C.J. McKay, C.R. Carter, E.J. Dickson, J.S. Graham, F. Duthie, K. Oien, J. Hair, J.P. Morton, O.J. Sansom, R. Grützmann, R.H. Hruban, A. Maitra, C.A. Iacobuzio-Donahue, R.D. Schulick, C.L. Wolfgang, R.A. Morgan, R.T. Lawlor, B. Rusev, V. Corbo, R. Salvia, I. Cataldo, G. Tortora, M.A. Tempero, O. Hofmann, J.R. Eshleman, C. Pilarsky, A. Scarpa, E.A. Musgrove, A.J. Gill, J.V. Pearson, S.M. Grimmond, N. Waddell, A.V. Biankin, Hypermutation in pancreatic cancer. Gastroenterology 152, 68-74 (2017)

33. S. Lemery, P. Keegan, R. Pazdur, First FDA approval agnostic of cancer site - when a biomarker defines the indication. N. Engl. J. Med. 377, 1409-1412 (2017)

34. Z.I. Hu, J. Shia, Z.K. Stadler, A.M. Varghese, M. Capanu, E. SaloMullen, M.A. Lowery, L.A. Diaz Jr., D. Mandelker, K.H. Yu, A. Zervoudakis, D.P. Kelsen, C.A. Iacobuzio-Donahue, D.S. Klimstra, L.B. Saltz, I.H. Sahin, E.M. O'Reilly, Evaluating mismatch repair deficiency in pancreatic adenocarcinoma: Challenges and recommendations. Clin. Cancer Res. 24, 1326-1336 (2018)

35. E. Nolan, P. Savas, A.N. Policheni, P.K. Darcy, F. Vaillant, C.P. Mintoff, S. Dushyanthen, M. Mansour, J.-M.B. Pang, S.B. Fox, C. Kathleen Cuningham Foundation Consortium for Research into Familial Breast, C.M. Perou, J.E. Visvader, D.H.D. Gray, S. Loi, G.J. Lindeman, Combined immune checkpoint blockade as a therapeutic strategy for BRCA1-mutated breast cancer. Sci. Transl. Med. 9, eaal4922 (2017)

36. K. Shindo, J. Yu, M. Suenaga, S. Fesharakizadeh, C. Cho, A. Macgregor-Das, A. Siddiqui, P.D. Witmer, K. Tamura, T.J. Song, J.A. Navarro Almario, A. Brant, M. Borges, M. Ford, T. Barkley, J. He, M.J. Weiss, C.L. Wolfgang, N.J. Roberts, R.H. Hruban, A.P. Klein, M. Goggins, Deleterious germline mutations in patients with apparently sporadic pancreatic adenocarcinoma. J. Clin. Oncol. 35, 3382-3390 (2017)

37. P. Bailey, D.K. Chang, K. Nones, A.L. Johns, A.-M. Patch, M.-C. Gingras, D.K. Miller, A.N. Christ, T.J.C. Bruxner, M.C. Quinn, C. Nourse, L.C. Murtaugh, I. Harliwong, S. Idrisoglu, S. Manning, E. Nourbakhsh, S. Wani, L. Fink, O. Holmes, V. Chin, M.J. Anderson, S. Kazakoff, C. Leonard, F. Newell, N. Waddell, S. Wood, Q. Xu, P.J. Wilson, N. Cloonan, K.S. Kassahn, D. Taylor, K. Quek, A. Robertson, L. Pantano, L. Mincarelli, L.N. Sanchez, L. Evers, J. Wu, M. Pinese, M.J. Cowley, M.D. Jones, E.K. Colvin, A.M. Nagrial, E.S. Humphrey, L.A. Chantrill, A. Mawson, J. Humphris, A. Chou, M. Pajic, C.J. Scarlett, A.V. Pinho, M. Giry-Laterriere, I. Rooman, J.S. Samra, J.G. Kench, J.A. Lovell, N.D. Merrett, C.W. Toon, K. Epari, N.Q. Nguyen, A. Barbour, N. Zeps, K. Moran-Jones, N.B. Jamieson, J.S. Graham, F. Duthie, K. Oien, J. Hair, R. Grützmann, A. Maitra, C.A. Iacobuzio-Donahue, C.L. Wolfgang, R.A. Morgan, R.T. Lawlor, V. Corbo, C. Bassi, B. Rusev, P. Capelli, R. Salvia, G. Tortora, D. Mukhopadhyay, G.M. Petersen, A.P.C.G. Initiative,
D.M. Munzy, W.E. Fisher, S.A. Karim, J.R. Eshleman, R.H. Hruban, C. Pilarsky, J.P. Morton, O.J. Sansom, A. Scarpa, E.A. Musgrove, U.-M.H. Bailey, O. Hofmann, R.L. Sutherland, D.A. Wheeler, A.J. Gill, R.A. Gibbs, J.V. Pearson, N. Waddell, A.V. Biankin, S.M. Grimmond, Genomic analyses identify molecular subtypes of pancreatic cancer. Nature 531, 47-52 (2016)

38. E.A. Collisson, A. Sadanandam, P. Olson, W.J. Gibb, M. Truitt, S. Gu, J. Cooc, J. Weinkle, G.E. Kim, L. Jakkula, H.S. Feiler, A.H. Ko, A.B. Olshen, K.L. Danenberg, M.A. Tempero, P.T. Spellman, D. Hanahan, J.W. Gray, Subtypes of pancreatic ductal adenocarcinoma and their differing responses to therapy. Nat. Med. 17, 500-503 (2011)

39. R.A. Moffitt, R. Marayati, E.L. Flate, K.E. Volmar, S.G. Loeza, K.A. Hoadley, N.U. Rashid, L.A. Williams, S.C. Eaton, A.H. Chung, J.K. Smyla, J.M. Anderson, H.J. Kim, D.J. Bentrem, M.S. Talamonti, C.A. Iacobuzio-Donahue, M.A. Hollingsworth, J.J. Yeh, Virtual microdissection identifies distinct tumor- and stroma-specific subtypes of pancreatic ductal adenocarcinoma. Nat. Genet. 47, 1168-1178 (2015)

40. P. Kvistborg, D. Philips, S. Kelderman, L. Hageman, C. Ottensmeier, D. Joseph-Pietras, M.J. Welters, S. van der Burg, E. Kapiteijn, O. Michielin, E. Romano, C. Linnemann, D. Speiser, C. Blank, J.B. Haanen, T.N. Schumacher, Anti-CTLA4 therapy broadens the melanoma-reactive $\mathrm{CD} 8+\mathrm{T}$ cell response. Sci. Trans. Med. 6, 254ra128 (2014)

41. W.H. Fridman, L. Zitvogel, C. Sautes-Fridman, G. Kroemer, The immune contexture in cancer prognosis and treatment. Nat. Rev. Clin. Oncol. 14, 717-734 (2017)

42. A. Fukunaga, M. Miyamoto, Y. Cho, S. Murakami, Y. Kawarada, T. Oshikiri, K. Kato, T. Kurokawa, M. Suzuoki, Y. Nakakubo, K. Hiraoka, T. Itoh, T. Morikawa, S. Okushiba, S. Kondo, H. Katoh, CD8+ tumor-infiltrating lymphocytes together with CD4+ tumorinfiltrating lymphocytes and dendritic cells improve the prognosis of patients with pancreatic adenocarcinoma. Pancreas 28, e26-e31 (2004)

43. Y. Ino, R. Yamazaki-Itoh, K. Shimada, M. Iwasaki, T. Kosuge, Y. Kanai, N. Hiraoka, Immune cell infiltration as an indicator of the immune microenvironment of pancreatic cancer. Br. J. Cancer 108, 914-923 (2013)

44. J. Blando, A. Sharma, M.G. Higa, H. Zhao, L. Vence, S.S. Yadav, J. Kim, A.M. Sepulveda, M. Sharp, A. Maitra, J. Wargo, M. Tetzlaff, R. Broaddus, M.H.G. Katz, G.R. Varadhachary, M. Overman, H. Wang, C. Yee, C. Bernatchez, C. IacobuzioDonahue, S. Basu, J.P. Allison, P. Sharma, Comparison of immune infiltrates in melanoma and pancreatic cancer highlights VISTA as a potential target in pancreatic cancer. Proc. Natl. Acad. Sci. USA 116, 1692-1697 (2019)

45. M.B. Wachsmann, L.M. Pop, E.S. Vitetta, Pancreatic ductal adenocarcinoma: a review of immunologic aspects. J. Investig. Med. 60, 643-663 (2012)

46. E. Tassi, F. Gavazzi, L. Albarello, V. Senyukov, R. Longhi, P. Dellabona, C. Doglioni, M. Braga, V. Di Carlo, M.P. Protti, Carcinoembryonic antigen-specific but not antiviral CD4+ T cell immunity is impaired in pancreatic carcinoma patients. J. Immunol. 181, 6595-6603 (2008)

47. L. De Monte, M. Reni, E. Tassi, D. Clavenna, I. Papa, H. Recalde, M. Braga, V. Di Carlo, C. Doglioni, M.P. Protti, Intratumor T helper type 2 cell infiltrate correlates with cancer-associated fibroblast thymic stromal lymphopoietin production and reduced survival in pancreatic cancer. J. Exp. Med. 208, 469-478 (2011)

48. K.L. Dennis, N.R. Blatner, F. Gounari, K. Khazaie, Current status of interleukin-10 and regulatory T-cells in cancer. Curr. Opin. Oncol. 25, 637-645 (2013)

49. L. Fahlen, S. Read, L. Gorelik, S.D. Hurst, R.L. Coffman, R.A. Flavell, F. Powrie, T cells that cannot respond to TGF-beta escape 
control by CD4(+)CD25(+) regulatory T cells. J. Exp. Med. 201, 737-746 (2005)

50. Y. Zhang, J. Lazarus, N.G. Steele, W. Yan, H.J. Lee, Z.C. Nwosu, C.J. Halbrook, R.E. Menjivar, S.B. Kemp, V.R. Sirihorachai, A. Velez-Delgado, K. Donahue, E.S. Carpenter, K.L. Brown, V. Irizarry-Negron, A.C. Nevison, A. Vinta, M.A. Anderson, H.C. Crawford, C.A. Lyssiotis, T.L. Frankel, F. Bednar, M. Pasca di Magliano, Regulatory T-cell depletion alters the tumor microenvironment and accelerates pancreatic carcinogenesis. Cancer Discov. 10, 422-439 (2020)

51. B. Shang, Y. Liu, S.J. Jiang, Y. Liu, Prognostic value of tumorinfiltrating FoxP3+ regulatory $\mathrm{T}$ cells in cancers: a systematic review and meta-analysis. Sci. Rep. 5, 15179 (2015)

52. M. Laviron, A. Boissonnas, Ontogeny of tumor-associated macrophages. Front. Immunol. 10, 1799 (2019)

53. A. Mielgo, M.C. Schmid, Impact of tumour associated macrophages in pancreatic cancer. BMB Rep. 46, 131-138 (2013)

54. R.A. Franklin, M.O. Li, Ontogeny of tumor-associated macrophages and its implication in cancer regulation. Trends Cancer 2, 20-34 (2016)

55. Y. Zhu, J.M. Herndon, D.K. Sojka, K.W. Kim, B.L. Knolhoff, C. Zuo, D.R. Cullinan, J. Luo, A.R. Bearden, K.J. Lavine, W.M. Yokoyama, W.G. Hawkins, R.C. Fields, G.J. Randolph, D.G. DeNardo, Tissue-resident macrophages in pancreatic ductal adenocarcinoma originate from embryonic hematopoiesis and promote tumor progression. Immunity 47, 323-338 e326 (2017)

56. A. Wang-Gillam, E.M. O'Reilly, J.C. Bendell, Z.A. Wainberg, E.H. Borazanci, N. Bahary, M.H. O'Hara, G.L. Beatty, S. Pant, D.J. Cohen, S. Leong, M.S. Beg, K.H. Yu, T.R.J. Evans, T. Seufferlein, T. Okusaka, P. Phillips, X. Liu, S.K. Perna, D.T. Le, A randomized phase II study of cabiralizumab (cabira) + nivolumab (nivo) \pm chemotherapy (chemo) in advanced pancreatic ductal adenocarcinoma (PDAC). 37, TPS465-TPS465 (2019)

57. Y. Zhu, B.L. Knolhoff, M.A. Meyer, T.M. Nywening, B.L. West, J. Luo, A. Wang-Gillam, S.P. Goedegebuure, D.C. Linehan, D.G. De Nardo, CSF1/CSF1R blockade reprograms tumor-infiltrating macrophages and improves response to T-cell checkpoint immunotherapy in pancreatic cancer models. Cancer Res. 74, 50575069 (2014)

58. Y.S. Khaled, B.J. Ammori, E. Elkord, Increased levels of granulocytic myeloid-derived suppressor cells in peripheral blood and tumour tissue of pancreatic cancer patients. J. Immunol. Res. 2014, 879897 (2014)

59. J. Markowitz, T.R. Brooks, M.C. Duggan, B.K. Paul, X. Pan, L. Wei, Z. Abrams, E. Luedke, G.B. Lesinski, B. Mundy-Bosse, T. Bekaii-Saab, W.E. Carson 3rd, Patients with pancreatic adenocarcinoma exhibit elevated levels of myeloid-derived suppressor cells upon progression of disease. Cancer Immunol. Immunother. 64, 149-159 (2015)

60. R.F. Gabitass, N.E. Annels, D.D. Stocken, H.A. Pandha, G.W. Middleton, Elevated myeloid-derived suppressor cells in pancreatic, esophageal and gastric cancer are an independent prognostic factor and are associated with significant elevation of the Th2 cytokine interleukin-13. Cancer Immunol. Immunother. 60, 1419-1430 (2011)

61. S. Ostrand-Rosenberg, P. Sinha, D.W. Beury, V.K. Clements, Cross-talk between myeloid-derived suppressor cells (MDSC), macrophages, and dendritic cells enhances tumor-induced immune suppression. Semin. Cancer Biol. 22, 275-281 (2012)

62. J. Markowitz, J. Wang, Z. Vangundy, J. You, V. Yildiz, L. Yu, I.P. Foote, O.E. Branson, A.R. Stiff, T.R. Brooks, B. Biesiadecki, T. Olencki, S. Tridandapani, M.A. Freitas, T. Papenfuss, M.A. Phelps, W.E. Carson, Nitric oxide mediated inhibition of antigen presentation from DCs to CD4(+) T cells in cancer and measurement of STAT1 nitration. Sci. Rep. 7, 15424 (2017)
63. G. Bellone, A. Carbone, C. Smirne, T. Scirelli, A. Buffolino, A. Novarino, A. Stacchini, O. Bertetto, G. Palestro, C. Sorio, A. Scarpa, G. Emanuelli, U. Rodeck, Cooperative induction of a tolerogenic dendritic cell phenotype by cytokines secreted by pancreatic carcinoma cells. J. Immunol. 177, 3448-3460 (2006)

64. J.A. Kenkel, W.W. Tseng, M.G. Davidson, L.L. Tolentino, O. Choi, N. Bhattacharya, E.S. Seeley, D.A. Winer, N.E. RetickerFlynn, E.G. Engleman, An Immunosuppressive dendritic cell subset accumulates at secondary sites and promotes metastasis in pancreatic cancer. Cancer Res. 77, 4158-4170 (2017)

65. H. Miyamoto, T. Murakami, K. Tsuchida, H. Sugino, H. Miyake, S. Tashiro, Tumor-stroma interaction of human pancreatic cancer: acquired resistance to anticancer drugs and proliferation regulation is dependent on extracellular matrix proteins. Pancreas 28, 38-44 (2004)

66. J.A. Joyce, D.T. Fearon, T cell exclusion, immune privilege, and the tumor microenvironment. Science 348, 74-80 (2015)

67. Q. Sun, B. Zhang, Q. Hu, Y. Qin, W. Xu, W. Liu, X. Yu, J. Xu, The impact of cancer-associated fibroblasts on major hallmarks of pancreatic cancer. Theranostics 8, 5072-5087 (2018)

68. P. Lu, V.M. Weaver, Z. Werb, The extracellular matrix: a dynamic niche in cancer progression. J. Cell Biol. 196, 395-406 (2012)

69. M. Ligorio, S. Sil, J. Malagon-Lopez, L.T. Nieman, S. Misale, M. Di Pilato, R.Y. Ebright, M.N. Karabacak, A.S. Kulkarni, A. Liu, N.V. Jordan, J.W. Franses, J. Philipp, J. Kreuzer, N. Desai, K.S. Arora, M. Rajurkar, E. Horwitz, A. Neyaz, E. Tai, N.K.C. Magnus, K.D. Vo, C.N. Yashaswini, F. Marangoni, M. Boukhali, J.P. Fatherree, L.J. Damon, K. Xega, R. Desai, M. Choz, F. Bersani, A. Langenbucher, V. Thapar, R. Morris, U.F. Wellner, O. Schilling, M.S. Lawrence, A.S. Liss, M.N. Rivera, V. Deshpande, C.H. Benes, S. Maheswaran, D.A. Haber, C. Fernandez-Del-Castillo, C.R. Ferrone, W. Haas, M.J. Aryee, D.T. Ting, Stromal microenvironment shapes the intratumoral architecture of pancreatic cancer. Cell 178, 160-175 e127 (2019)

70. S. Yamaki, H. Yanagimoto, K. Tsuta, H. Ryota, M. Kon, PD-L1 expression in pancreatic ductal adenocarcinoma is a poor prognostic factor in patients with high $\mathrm{CD} 8(+)$ tumor-infiltrating lymphocytes: highly sensitive detection using phosphor-integrated dot staining. Int. J. Clin. Oncol. 22, 726-733 (2017)

71. T. Nomi, M. Sho, T. Akahori, K. Hamada, A. Kubo, H. Kanehiro, S. Nakamura, K. Enomoto, H. Yagita, M. Azuma, Y. Nakajima, Clinical significance and therapeutic potential of the programmed death-1 ligand/programmed death-1 pathway in human pancreatic cancer. Clin. Cancer Res. 13, 2151-2157 (2007)

72. E.S. Knudsen, P. Vail, U. Balaji, H. Ngo, I. Botros, V. Makarov, Stratification of pancreatic ductal adenocarcinoma: Combinatorial genetic, stromal, and immunological markers. Clin. Cancer Res. 23, 4429-4440 (2017)

73. L. Gandhi, D. Rodriguez-Abreu, S. Gadgeel, E. Esteban, E. Felip, F. De Angelis, M. Domine, P. Clingan, M.J. Hochmair, S.F. Powell, S.Y. Cheng, H.G. Bischoff, N. Peled, F. Grossi, R.R. Jennens, M. Reck, R. Hui, E.B. Garon, M. Boyer, B. RubioViqueira, S. Novello, T. Kurata, J.E. Gray, J. Vida, Z. Wei, J. Yang, H. Raftopoulos, M.C. Pietanza, M.C. Garassino, K. Investigators, pembrolizumab plus chemotherapy in metastatic non-small-cell lung cancer. N. Engl. J. Med. 378(2078-2092) (2018)

74. R. Govindan, A. Szczesna, M.J. Ahn, C.P. Schneider, P.F. Gonzalez Mella, F. Barlesi, B. Han, D.E. Ganea, J. Von Pawel, V. Vladimirov, N. Fadeeva, K.H. Lee, T. Kurata, L. Zhang, T. Tamura, P.E. Postmus, J. Jassem, K. O'Byrne, J. Kopit, M. Li, M. Tschaika, M. Reck, Phase III tial of Ipilimumab combined with Paclitaxel and Carboplatin in advanced squamous non-small-cell lung cancer. J. Clin. Oncol. 35, 3449-3457 (2017)

75. L. Voorwerk, M. Slagter, H.M. Horlings, K. Sikorska, K.K. van de Vijver, M. de Maaker, I. Nederlof, R.J.C. Kluin, S. Warren, S. 
Ong, T.G. Wiersma, N.S. Russell, F. Lalezari, P.C. Schouten, N.A.M. Bakker, S.L.C. Ketelaars, D. Peters, C.A.H. Lange, E. van Werkhoven, H. van Tinteren, I.A.M. Mandjes, I. Kemper, S. Onderwater, M. Chalabi, S. Wilgenhof, J. Haanen, R. Salgado, K.E. de Visser, G.S. Sonke, L.F.A. Wessels, S.C. Linn, T.N. Schumacher, C.U. Blank, M. Kok, Immune induction strategies in metastatic triple-negative breast cancer to enhance the sensitivity to PD-1 blockade: the TONIC trial. Nat. Med. 25, 920-928 (2019)

76. W.M. Liu, D.W. Fowler, P. Smith, A.G. Dalgleish, Pre-treatment with chemotherapy can enhance the antigenicity and immunogenicity of tumours by promoting adaptive immune responses. Br. J. Cancer 102, 115-123 (2010)

77. J. Vincent, G. Mignot, F. Chalmin, S. Ladoire, M. Bruchard, A. Chevriaux, F. Martin, L. Apetoh, C. Rebe, F. Ghiringhelli, 5Fluorouracil selectively kills tumor-associated myeloid-derived suppressor cells resulting in enhanced T cell-dependent antitumor immunity. Cancer Res. 70, 3052-3061 (2010)

78. C. Banissi, F. Ghiringhelli, L. Chen, A.F. Carpentier, Treg depletion with a low-dose metronomic temozolomide regimen in a rat glioma model. Cancer Immunol. Immunother. 58, 1627-1634 (2009)

79. L. Bezu, L.C. Gomes-de-Silva, H. Dewitte, K. Breckpot, J. Fucikova, R. Spisek, L. Galluzzi, O. Kepp, G. Kroemer, Combinatorial strategies for the induction of immunogenic cell death. Front. Immunol 6, 187 (2015)

80. Y. Ma, S. Adjemian, S.R. Mattarollo, T. Yamazaki, L. Aymeric, H. Yang, J.P. Portela Catani, D. Hannani, H. Duret, K. Steegh, I. Martins, F. Schlemmer, M. Michaud, O. Kepp, A.Q. Sukkurwala, L. Menger, E. Vacchelli, N. Droin, L. Galluzzi, R. Krzysiek, S. Gordon, P.R. Taylor, P. Van Endert, E. Solary, M.J. Smyth, L. Zitvogel, G. Kroemer, Anticancer chemotherapy-induced intratumoral recruitment and differentiation of antigen-presenting cells. Immunity 38, 729-741 (2013)

81. G. Di Caro, N. Cortese, G.F. Castino, F. Grizzi, F. Gavazzi, C. Ridolfi, G. Capretti, R. Mineri, J. Todoric, A. Zerbi, P. Allavena, A. Mantovani, F. Marchesi, Dual prognostic significance of tumour-associated macrophages in human pancreatic adenocarcinoma treated or untreated with chemotherapy. Gut $\mathbf{6 5}, 1710-1720$ (2016)

82. A. Tesniere, F. Schlemmer, V. Boige, O. Kepp, I. Martins, F. Ghiringhelli, L. Aymeric, M. Michaud, L. Apetoh, L. Barault, J. Mendiboure, J.P. Pignon, V. Jooste, P. van Endert, M. Ducreux, L. Zitvogel, F. Piard, G. Kroemer, Immunogenic death of colon cancer cells treated with oxaliplatin. Oncogene 29, 482-491 (2010)

83. S.J. Bains, H. Abrahamsson, K. Flatmark, S. Dueland, K.H. Hole, T. Seierstad, K.R. Redalen, S. Meltzer, A.H. Ree, Immunogenic cell death by neoadjuvant oxaliplatin and radiation protects against metastatic failure in high-risk rectal cancer. Cancer Immunol. Immunother. 69, 355-364 (2020)

84. J.W. Hodge, C.T. Garnett, B. Farsaci, C. Palena, K.Y. Tsang, S. Ferrone, S.R. Gameiro, Chemotherapy-induced immunogenic modulation of tumor cells enhances killing by cytotoxic $\mathrm{T}$ lymphocytes and is distinct from immunogenic cell death. Int. J. Cancer 133, 624-636 (2013)

85. M. Aglietta, C. Barone, M.B. Sawyer, M.J. Moore, W.H. Miller Jr., C. Bagala, F. Colombi, C. Cagnazzo, L. Gioeni, E. Wang, B. Huang, K.D. Fly, F. Leone, A phase I dose escalation trial of tremelimumab (CP-675,206) in combination with gemcitabine in chemotherapy-naive patients with metastatic pancreatic cancer. Ann. Oncol. 25, 1750-1755 (2014)

86. G.J. Weiss, J. Waypa, L. Blaydorn, J. Coats, K. McGahey, A. Sangal, J. Niu, C.A. Lynch, J.H. Farley, V. Khemka, A phase Ib study of pembrolizumab plus chemotherapy in patients with advanced cancer (PembroPlus). Br. J. Cancer 117, 33-40 (2017)
87. G.J. Weiss, L. Blaydorn, J. Beck, K. Bornemann-Kolatzki, H. Urnovitz, E. Schutz, V. Khemka, Phase Ib/II study of gemcitabine, nab-paclitaxel, and pembrolizumab in metastatic pancreatic adenocarcinoma. Invest. New Drugs 36, 96-102 (2018)

88. Y. Lee, S.L. Auh, Y. Wang, B. Burnette, Y. Wang, Y. Meng, M. Beckett, R. Sharma, R. Chin, T. Tu, R.R. Weichselbaum, Y.X. Fu, Therapeutic effects of ablative radiation on local tumor require CD8+ T cells: changing strategies for cancer treatment. Blood 114, 589-595 (2009)

89. L. Apetoh, F. Ghiringhelli, A. Tesniere, M. Obeid, C. Ortiz, A. Criollo, G. Mignot, M.C. Maiuri, E. Ullrich, P. Saulnier, H. Yang, S. Amigorena, B. Ryffel, F.J. Barrat, P. Saftig, F. Levi, R. Lidereau, C. Nogues, J.P. Mira, A. Chompret, V. Joulin, F. Clavel-Chapelon, J. Bourhis, F. Andre, S. Delaloge, T. Tursz, G. Kroemer, L. Zitvogel, Toll-like receptor 4-dependent contribution of the immune system to anticancer chemotherapy and radiotherapy. Nat. Med. 13, 1050-1059 (2007)

90. A.A. Lugade, J.P. Moran, S.A. Gerber, R.C. Rose, J.G. Frelinger, E.M. Lord, Local radiation therapy of B16 melanoma tumors increases the generation of tumor antigen-specific effector cells that traffic to the tumor. J. Immunol. 174, 7516-7523 (2005)

91. E.A. Reits, J.W. Hodge, C.A. Herberts, T.A. Groothuis, M. Chakraborty, E.K. Wansley, K. Camphausen, R.M. Luiten, A.H. de Ru, J. Neijssen, A. Griekspoor, E. Mesman, F.A. Verreck, H. Spits, J. Schlom, P. van Veelen, J.J. Neefjes, Radiation modulates the peptide repertoire, enhances MHC class I expression, and induces successful antitumor immunotherapy. J. Exp. Med. 203, 1259-1271 (2006)

92. C. Twyman-Saint Victor, A.J. Rech, A. Maity, R. Rengan, K.E. Pauken, E. Stelekati, J.L. Benci, B. Xu, H. Dada, P.M. Odorizzi, R.S. Herati, K.D. Mansfield, D. Patsch, R.K. Amaravadi, L.M. Schuchter, H. Ishwaran, R. Mick, D.A. Pryma, X. Xu, M.D. Feldman, T.C. Gangadhar, S.M. Hahn, E.J. Wherry, R.H. Vonderheide, A.J. Minn, Radiation and dual checkpoint blockade activate non-redundant immune mechanisms in cancer. Nature 520, 373-377 (2015)

93. F. Shi, X. Wang, F. Teng, L. Kong, J. Yu, Abscopal effect of metastatic pancreatic cancer after local radiotherapy and granulocyte-macrophage colony-stimulating factor therapy. Cancer Biol. Ther. 18, 137-141 (2017)

94. C.L. Haymaker, D. Kim, M. Uemura, L.M. Vence, A. Phillip, N. McQuail, P.D. Brown, I. Fernandez, C.W. Hudgens, C. Creasy, W.J. Hwu, P. Sharma, M.T. Tetzlaff, J.P. Allison, P. Hwu, C. Bernatchez, A. Diab, Metastatic melanoma patient had a complete response with clonal expansion after whole brain radiation and PD-1 blockade. Cancer Immunol. Res. 5, 100-105 (2017)

95. S.J. Antonia, A. Villegas, D. Daniel, D. Vicente, S. Murakami, R. Hui, T. Yokoi, A. Chiappori, K.H. Lee, M. de Wit, B.C. Cho, M. Bourhaba, X. Quantin, T. Tokito, T. Mekhail, D. Planchard, Y.C. Kim, C.S. Karapetis, S. Hiret, G. Ostoros, K. Kubota, J.E. Gray, L. Paz-Ares, J. de Castro Carpeno, C. Wadsworth, G. Melillo, H. Jiang, Y. Huang, P.A. Dennis, M. Ozguroglu, Durvalumab after chemoradiotherapy in stage III non-small-cell lung cancer. N. Engl. J. Med. 377, 1919-1929 (2017)

96. C.J.M. Melief, M.J.P. Welters, I. Vergote, J.R. Kroep, G.G. Kenter, P.B. Ottevanger, W.A.A. Tjalma, H. Denys, M.I.E. van Poelgeest, H.W. Nijman, A.K.L. Reyners, T. Velu, F. Goffin, R.I. Lalisang, N.M. Loof, S. Boekestijn, W.J. Krebber, L. Hooftman, S. Visscher, B.A. Blumenstein, R.B. Stead, W. Gerritsen, S.H. van der Burg, Strong vaccine responses during chemotherapy are associated with prolonged cancer survival. Sci. Transl. Med. 12, eaaz8235 (2020)

97. G.G. Kenter, M.J. Welters, A.R. Valentijn, M.J. Lowik, D.M. Berends-van der Meer, A.P. Vloon, F. Essahsah, L.M. Fathers, R. Offringa, J.W. Drijfhout, A.R. Wafelman, J. Oostendorp, G.J. Fleuren, S.H. van der Burg, C.J. Melief, Vaccination against 
HPV-16 oncoproteins for vulvar intraepithelial neoplasia. N. Engl. J. Med. 361, 1838-1847 (2009)

98. P.W. Kantoff, C.S. Higano, N.D. Shore, E.R. Berger, E.J. Small, D.F. Penson, C.H. Redfern, A.C. Ferrari, R. Dreicer, R.B. Sims, Y. Xu, M.W. Frohlich, P.F. Schellhammer, I.S. Investigators, Sipuleucel-T immunotherapy for castration-resistant prostate cancer. N. Engl. J. Med. 363, 411-422 (2010)

99. D. Salas-Benito, I. Melero, M. Ponz-Sarvise, Vaccination for pancreatic ductal adenocarcinoma: A hard nut to crack. Clin. Cancer Res. 25, 5435-5437 (2019)

100. E.M. Jaffee, R.H. Hruban, B. Biedrzycki, D. Laheru, K. Schepers, P.R. Sauter, M. Goemann, J. Coleman, L. Grochow, R.C. Donehower, K.D. Lillemoe, S. O'Reilly, R.A. Abrams, D.M. Pardoll, J.L. Cameron, C.J. Yeo, Novel allogeneic granulocytemacrophage colony-stimulating factor-secreting tumor vaccine for pancreatic cancer: a phase I trial of safety and immune activation. J. Clin. Oncol. 19, 145-156 (2001)

101. E.R. Lutz, A.A. Wu, E. Bigelow, R. Sharma, G. Mo, K. Soares, S. Solt, A. Dorman, A. Wamwea, A. Yager, D. Laheru, C.L. Wolfgang, J. Wang, R.H. Hruban, R.A. Anders, E.M. Jaffee, L. Zheng, Immunotherapy converts nonimmunogenic pancreatic tumors into immunogenic foci of immune regulation. Cancer Immunol. Res. 2, 616-631 (2014)

102. B.P. Keenan, E.M. Jaffee, Whole cell vaccines-past progress and future strategies. Semin. Oncol. 39, 276-286 (2012)

103. E. Lutz, C.J. Yeo, K.D. Lillemoe, B. Biedrzycki, B. Kobrin, J. Herman, E. Sugar, S. Piantadosi, J.L. Cameron, S. Solt, B. Onners, I. Tartakovsky, M. Choi, R. Sharma, P.B. Illei, R.H. Hruban, R.A. Abrams, D. Le, E. Jaffee, D. Laheru, A lethally irradiated allogeneic granulocyte-macrophage colony stimulating factor-secreting tumor vaccine for pancreatic adenocarcinoma. A Phase II trial of safety, efficacy, and immune activation. Ann. Surg. 253, 328-335 (2011)

104. A. Shimizu, S. Hirono, M. Tani, M. Kawai, K. Okada, M. Miyazawa, Y. Kitahata, Y. Nakamura, T. Noda, S. Yokoyama, $\mathrm{H}$. Yamaue, Coexpression of MUC16 and mesothelin is related to the invasion process in pancreatic ductal adenocarcinoma. Cancer Sci. 103, 739-746 (2012)

105. R. Hassan, A. Thomas, C. Alewine, D.T. Le, E.M. Jaffee, I. Pastan, Mesothelin immunotherapy for cancer: Ready for prime time? J. Clin. Oncol. 34, 4171-4179 (2016)

106. D.T. Le, A. Wang-Gillam, V. Picozzi, T.F. Greten, T. Crocenzi, G. Springett, M. Morse, H. Zeh, D. Cohen, R.L. Fine, B. Onners, J.N. Uram, D.A. Laheru, E.R. Lutz, S. Solt, A.L. Murphy, J. Skoble, E. Lemmens, J. Grous, T. Dubensky Jr., D.G. Brockstedt, E.M. Jaffee, Safety and survival with GVAX pancreas prime and Listeria Monocytogenes-expressing mesothelin (CRS207) boost vaccines for metastatic pancreatic cancer. J. Clin. Oncol. 33, 1325-1333 (2015)

107. D.T. Le, V.J. Picozzi, A.H. Ko, Z.A. Wainberg, H. Kindler, A. Wang-Gillam, P. Oberstein, M.A. Morse, H.J. Zeh 3rd, C. Weekes, T. Reid, E. Borazanci, T. Crocenzi, N.K. LoConte, B. Musher, D. Laheru, A. Murphy, C. Whiting, N. Nair, A. Enstrom, S. Ferber, D.G. Brockstedt, E.M. Jaffee, Results from a phase IIb, randomized, multicenter study of GVAX pancreas and CRS-207 compared with chemotherapy in adults with previously treated metastatic pancreatic adenocarcinoma (ECLIPSE Study). Clin. Cancer Res. 25, 5493-5502 (2019)

108. K.C. Soares, A.A. Rucki, A.A. Wu, K. Olino, Q. Xiao, Y. Chai, A. Wamwea, E. Bigelow, E. Lutz, L. Liu, S. Yao, R.A. Anders, D. Laheru, C.L. Wolfgang, B.H. Edil, R.D. Schulick, E.M. Jaffee, L. Zheng, PD-1/PD-L1 blockade together with vaccine therapy facilitates effector T-cell infiltration into pancreatic tumors. J. Immunother. 38, 1-11 (2015)

109. D.T. Le, E. Lutz, J.N. Uram, E.A. Sugar, B. Onners, S. Solt, L. Zheng, L.A. Diaz Jr., R.C. Donehower, E.M. Jaffee, D.A. Laheru,
Evaluation of ipilimumab in combination with allogeneic pancreatic tumor cells transfected with a GM-CSF gene in previously treated pancreatic cancer. J. Immunother. 36, 382-389 (2013)

110. T.N. Schumacher, W. Scheper, P. Kvistborg, Cancer neoantigens. Ann. Rev. Immunol. 37, 173-200 (2019)

111. P.A. Ott, Z. Hu, D.B. Keskin, S.A. Shukla, J. Sun, D.J. Bozym, W. Zhang, A. Luoma, A. Giobbie-Hurder, L. Peter, C. Chen, O. Olive, T.A. Carter, S. Li, D.J. Lieb, T. Eisenhaure, E. Gjini, J. Stevens, W.J. Lane, I. Javeri, K. Nellaiappan, A.M. Salazar, H. Daley, M. Seaman, E.I. Buchbinder, C.H. Yoon, M. Harden, N. Lennon, S. Gabriel, S.J. Rodig, D.H. Barouch, J.C. Aster, G. Getz, K. Wucherpfennig, D. Neuberg, J. Ritz, E.S. Lander, E.F. Fritsch, N. Hacohen, C.J. Wu, An immunogenic personal neoantigen vaccine for patients with melanoma. Nature 547, 217-221 (2017)

112. U. Sahin, E. Derhovanessian, M. Miller, B.P. Kloke, P. Simon, M. Lower, V. Bukur, A.D. Tadmor, U. Luxemburger, B. Schrors, T. Omokoko, M. Vormehr, C. Albrecht, A. Paruzynski, A.N. Kuhn, J. Buck, S. Heesch, K.H. Schreeb, F. Muller, I. Ortseifer, I. Vogler, E. Godehardt, S. Attig, R. Rae, A. Breitkreuz, C. Tolliver, M. Suchan, G. Martic, A. Hohberger, P. Sorn, J. Diekmann, J. Ciesla, O. Waksmann, A.K. Bruck, M. Witt, M. Zillgen, A. Rothermel, B. Kasemann, D. Langer, S. Bolte, M. Diken, S. Kreiter, R. Nemecek, C. Gebhardt, S. Grabbe, C. Holler, J. Utikal, C. Huber, C. Loquai, O. Tureci, Personalized RNA mutanome vaccines mobilize poly-specific therapeutic immunity against cancer. Nature 547, 222-226 (2017)

113. M.R. Parkhurst, P.F. Robbins, E. Tran, T.D. Prickett, J.J. Gartner, L. Jia, G. Ivey, Y.F. Li, M. El-Gamil, A. Lalani, J.S. Crystal, A. Sachs, E. Groh, S. Ray, L.T. Ngo, S. Kivitz, A. Pasetto, R. Yossef, F.J. Lowery, S.L. Goff, W. Lo, G. Cafri, D.C. Deniger, P. Malekzadeh, M. Ahmadzadeh, J.R. Wunderlich, R.P.T. Somerville, S.A. Rosenberg, Unique neoantigens arise from somatic mutations in patients with gastrointestinal cancers. Cancer Discov. 9, 1022-1035 (2019)

114. K. Sonntag, H. Hashimoto, M. Eyrich, M. Menzel, M. Schubach, D. Docker, F. Battke, C. Courage, H. Lambertz, R. Handgretinger, S. Biskup, K. Schilbach, Immune monitoring and TCR sequencing of CD4 $\mathrm{T}$ cells in a long term responsive patient with metastasized pancreatic ductal carcinoma treated with individualized, neoepitope-derived multipeptide vaccines: a case report. J. Transl. Med 16, 23 (2018)

115. N. Waddell, M. Pajic, A.-M. Patch, D.K. Chang, K.S. Kassahn, P. Bailey, A.L. Johns, D.K. Miller, K. Nones, K. Quek, M.C. Quinn, E.A. Musgrove, J.V. Pearson, A.V. Biankin, Grimmond, Whole genomes redefine the mutational landscape of pancreatic cancer. Nature, 518, 495-501 (2015)

116. M.K. Gjertsen, T. Buanes, A.R. Rosseland, A. Bakka, I. Gladhaug, O. Soreide, J.A. Eriksen, M. Moller, I. Baksaas, R.A. Lothe, I. Saeterdal, G. Gaudernack, Intradermal ras peptide vaccination with granulocyte-macrophage colony-stimulating factor as adjuvant: Clinical and immunological responses in patients with pancreatic adenocarcinoma. Int. J. Cancer 92, 441-450 (2001)

117. S. Weden, M. Klemp, I.P. Gladhaug, M. Moller, J.A. Eriksen, G. Gaudernack, T. Buanes, Long-term follow-up of patients with resected pancreatic cancer following vaccination against mutant K-ras. Int. J. Cancer 128, 1120-1128 (2011)

118. N. Suzuki, S. Hazama, H. Iguchi, K. Uesugi, H. Tanaka, K. Hirakawa, A. Aruga, T. Hatori, H. Ishizaki, Y. Umeda, T. Fujiwara, T. Ikemoto, M. Shimada, K. Yoshimatsu, R. Shimizu, H. Hayashi, K. Sakata, H. Takenouchi, H. Matsui, Y. Shindo, M. Iida, Y. Koki, H. Arima, H. Furukawa, T. Ueno, S. Yoshino, Y. Nakamura, M. Oka, H. Nagano, Phase II clinical trial of peptide cocktail therapy for patients with advanced pancreatic cancer: VENUS-PC study. Cancer Sci. 108, 73-80 (2017) 
119. M. Miyazawa, M. Katsuda, H. Maguchi, A. Katanuma, H. Ishii, M. Ozaka, K. Yamao, H. Imaoka, M. Kawai, S. Hirono, K.I. Okada, H. Yamaue, Phase II clinical trial using novel peptide cocktail vaccine as a postoperative adjuvant treatment for surgically resected pancreatic cancer patients. Int. J. Cancer 140, 973982 (2017)

120. A.G. Bodnar, M. Ouellette, M. Frolkis, S.E. Holt, C.P. Chiu, G.B. Morin, C.B. Harley, J.W. Shay, S. Lichtsteiner, W.E. Wright, Extension of life-span by introduction of telomerase into normal human cells. Science 279, 349-352 (1998)

121. S.L. Bernhardt, M.K. Gjertsen, S. Trachsel, M. Moller, J.A. Eriksen, M. Meo, T. Buanes, G. Gaudernack, Telomerase peptide vaccination of patients with non-resectable pancreatic cancer: A dose escalating phase I/II study. Br. J. Cancer 95, 1474-1482 (2006)

122. G. Middleton, P. Silcocks, T. Cox, J. Valle, J. Wadsley, D. Propper, F. Coxon, P. Ross, S. Madhusudan, T. Roques, D. Cunningham, S. Falk, N. Wadd, M. Harrison, P. Corrie, T. Iveson, A. Robinson, K. McAdam, M. Eatock, J. Evans, C. Archer, T. Hickish, A. Garcia-Alonso, M. Nicolson, W. Steward, A. Anthoney, W. Greenhalf, V. Shaw, E. Costello, D. Naisbitt, C. Rawcliffe, G. Nanson, J. Neoptolemos, Gemcitabine and capecitabine with or without telomerase peptide vaccine GV1001 in patients with locally advanced or metastatic pancreatic cancer (TeloVac): an open-label, randomised, phase 3 trial. Lancet Oncol. 15, 829-840 (2014)

123. A. Howells, G. Marelli, N.R. Lemoine, Y. Wang, Oncolytic viruses-interaction of virus and tumor cells in the battle to eliminate cancer. Front. Oncol. 7, 195 (2017)

124. S.E. Lawler, M.C. Speranza, C.F. Cho, E.A. Chiocca, Oncolytic viruses in cancer treatment: A review. JAMA Oncol. 3, 841-849 (2017)

125. H. Kasuya, S. Takeda, S. Nomoto, A. Nakao, The potential of oncolytic virus therapy for pancreatic cancer. Cancer Gene Ther. 12, 725-736 (2005)

126. J.R. Bischoff, D.H. Kirn, A. Williams, C. Heise, S. Horn, M. Muna, L. Ng, J.A. Nye, A. Sampson-Johannes, A. Fattaey, F. McCormick, An adenovirus mutant that replicates selectively in p53-deficient human tumor cells. Science 274, 373-376 (1996)

127. C. Heise, A. Sampson-Johannes, A. Williams, F. McCormick, D.D. Von Hoff, D.H. Kirn, ONYX-015, an E1B gene-attenuated adenovirus, causes tumor-specific cytolysis and antitumoral efficacy that can be augmented by standard chemotherapeutic agents. Nat. Med. 3, 639-645 (1997)

128. S. Mulvihill, R. Warren, A. Venook, A. Adler, B. Randlev, C. Heise, D. Kirn, Safety and feasibility of injection with an E1B$55 \mathrm{kDa}$ gene-deleted, replication-selective adenovirus (ONYX015 ) into primary carcinomas of the pancreas: a phase I trial. Gene Ther. 8, 308-315 (2001)

129. J.R. Hecht, R. Bedford, J.L. Abbruzzese, S. Lahoti, T.R. Reid, R.M. Soetikno, D.H. Kirn, S.M. Freeman, A phase I/II trial of intratumoral endoscopic ultrasound injection of ONYX-015 with intravenous gemcitabine in unresectable pancreatic carcinoma. Clin. Cancer Res. 9, 555-561 (2003)

130. A. Nakao, H. Kasuya, T.T. Sahin, N. Nomura, A. Kanzaki, M. Misawa, T. Shirota, S. Yamada, T. Fujii, H. Sugimoto, T. Shikano, S. Nomoto, S. Takeda, Y. Kodera, Y. Nishiyama, A phase I dose-escalation clinical trial of intraoperative direct intratumoral injection of HF10 oncolytic virus in non-resectable patients with advanced pancreatic cancer. Cancer Gene Ther. 18, 167-175 (2011)

131. Y. Hirooka, H. Kasuya, T. Ishikawa, H. Kawashima, E. Ohno, I.B. Villalobos, Y. Naoe, T. Ichinose, N. Koyama, M. Tanaka, Y. Kodera, H. Goto, A Phase I clinical trial of EUS-guided intratumoral injection of the oncolytic virus, HF10 for unresectable locally advanced pancreatic cancer. BMC Cancer 18, 596 (2018)

132. J. Hajda, M. Lehmann, O. Krebs, M. Kieser, K. Geletneky, D. Jager, M. Dahm, B. Huber, T. Schoning, O. Sedlaczek, A. Stenzinger, N. Halama, V. Daniel, B. Leuchs, A. Angelova, J. Rommelaere, C.E. Engeland, C. Springfeld, G. Ungerechts, A non-controlled, single arm, open label, phase II study of intravenous and intratumoral administration of ParvOryx in patients with metastatic, inoperable pancreatic cancer: ParvOryx02 protocol. BMC Cancer 17, 576 (2017)

133. A.M. Noonan, M.R. Farren, S.M. Geyer, Y. Huang, S. Tahiri, D. Ahn, S. Mikhail, K.K. Ciombor, S. Pant, S. Aparo, J. Sexton, J.L. Marshall, T.A. Mace, C.S. Wu, B. El-Rayes, C.D. Timmers, J. Zwiebel, G.B. Lesinski, M.A. Villalona-Calero, T.S. BekaiiSaab, Randomized phase 2 trial of the oncolytic virus pelareorep (Reolysin) in upfront treatment of metastatic pancreatic adenocarcinoma. Mol. Ther. 24, 1150-1158 (2016)

134. D. Mahalingam, S. Goel, S. Aparo, S. Patel Arora, N. Noronha, H. Tran, R. Chakrabarty, G. Selvaggi, A. Gutierrez, M. Coffey, S.T. Nawrocki, G. Nuovo, M.M. Mita, A phase II study of pelareorep (REOLYSIN $((\mathrm{R})))$ in combination with gemcitabine for patients with advanced pancreatic adenocarcinoma. Cancers (Basel) 10, 160 (2018)

135. V. Kemp, D.J.M. van den Wollenberg, M.G.M. Camps, T. van Hall, P. Kinderman, N. Pronk-van Montfoort, R.C. Hoeben, Arming oncolytic reovirus with GM-CSF gene to enhance immunity. Cancer Gene Ther. 26, 268-281 (2019)

136. J.C. Hu, R.S. Coffin, C.J. Davis, N.J. Graham, N. Groves, P.J. Guest, K.J. Harrington, N.D. James, C.A. Love, I. McNeish, L.C. Medley, A. Michael, C.M. Nutting, H.S. Pandha, C.A. Shorrock, J. Simpson, J. Steiner, N.M. Steven, D. Wright, R.C. Coombes, A phase I study of OncoVEXGM-CSF, a secondgeneration oncolytic herpes simplex virus expressing granulocyte macrophage colony-stimulating factor. Clin. Cancer Res. 12, 6737-6747 (2006)

137. N.N. Senzer, H.L. Kaufman, T. Amatruda, M. Nemunaitis, T. Reid, G. Daniels, R. Gonzalez, J. Glaspy, E. Whitman, K. Harrington, H. Goldsweig, T. Marshall, C. Love, R. Coffin, J.J. Nemunaitis, Phase II clinical trial of a granulocyte-macrophage colony-stimulating factor-encoding, second-generation oncolytic herpesvirus in patients with unresectable metastatic melanoma. J. Clin. Oncol. 27, 5763-5771 (2009)

138. G. Wang, X. Kang, K.S. Chen, T. Jehng, L. Jones, J. Chen, X.F. Huang, S.Y. Chen, An engineered oncolytic virus expressing PD$\mathrm{L} 1$ inhibitors activates tumor neoantigen-specific $\mathrm{T}$ cell responses. Nat. Commun. 11, 1395 (2020)

139. S.A. Rosenberg, N.P. Restifo, Adoptive cell transfer as personalized immunotherapy for human cancer. Science 348, 62-68 (2015)

140. I.M. Svane, E.M. Verdegaal, Achievements and challenges of adoptive $\mathrm{T}$ cell therapy with tumor-infiltrating or blood-derived lymphocytes for metastatic melanoma: what is needed to achieve standard of care? Cancer Immunol. Immunother. 63, 1081-1091 (2014)

141. A.I. Ali, A.J. Oliver, T. Samiei, J.D. Chan, M.H. Kershaw, C.Y. Slaney, Genetic redirection T cells for the treatment of pancreatic cancer. Front. Oncol. 9, 56 (2019)

142. Z. Eshhar, T. Waks, G. Gross, D.G. Schindler, Specific activation and targeting of cytotoxic lymphocytes through chimeric single chains consisting of antibody-binding domains and the gamma or zeta subunits of the immunoglobulin and T-cell receptors. Proc. Natl. Acad. Sci. U S A 90, 720-724 (1993)

143. J.H. Park, I. Riviere, M. Gonen, X. Wang, B. Senechal, K.J. Curran, C. Sauter, Y. Wang, B. Santomasso, E. Mead, M. Roshal, P. Maslak, M. Davila, R.J. Brentjens, M. Sadelain, 
Long-term follow-up of CD19 CAR therapy in acute lymphoblastic leukemia. N. Engl. J. Med. 378, 449-459 (2018)

144. K. Newick, E. Moon, S.M. Albelda, Chimeric antigen receptor Tcell therapy for solid tumors. Mol. Ther. Oncolytics 3, 16006 (2016)

145. M. Akce, M.Y. Zaidi, E.K. Waller, B.F. El-Rayes, G.B. Lesinski, The potential of CAR T cell therapy in pancreatic cancer. Front. Immunol 9, 2166 (2018)

146. A.D. Posey Jr., R.D. Schwab, A.C. Boesteanu, C. Steentoft, U. Mandel, B. Engels, J.D. Stone, T.D. Madsen, K. Schreiber, K.M. Haines, A.P. Cogdill, T.J. Chen, D. Song, J. Scholler, D.M. Kranz, M.D. Feldman, R. Young, B. Keith, H. Schreiber, H. Clausen, L.A. Johnson, C.H. June, Engineered CAR T cells targeting the cancer-associated Tn-Glycoform of the membrane mucin MUC1 controls adenocarcinoma. Immunity 44, 1444-1454 (2016)

147. M. Chmielewski, O. Hahn, G. Rappl, M. Nowak, I.H. SchmidtWolf, A.A. Hombach, H. Abken, T cells that target carcinoembryonic antigen eradicate orthotopic pancreatic carcinomas without inducing autoimmune colitis in mice. Gastroenterology 143, 1095-1107.e1092 (2012)

148. A. Maliar, C. Servais, T. Waks, M. Chmielewski, R. Lavy, P. Altevogt, H. Abken, Z. Eshhar, Redirected T cells that target pancreatic adenocarcinoma antigens eliminate tumors and metastases in mice. Gastroenterology 143, 1375-1384.e1375 (2012)

149. F.C. Thistlethwaite, D.E. Gilham, R.D. Guest, D.G. Rothwell, M. Pillai, D.J. Burt, A.J. Byatte, N. Kirillova, J.W. Valle, S.K. Sharma, K.A. Chester, N.B. Westwood, S.E.R. Halford, S. Nabarro, S. Wan, E. Austin, R.E. Hawkins, The clinical efficacy of first-generation carcinoembryonic antigen (CEACAM5)-specific CAR $\mathrm{T}$ cells is limited by poor persistence and transient pre-conditioning-dependent respiratory toxicity. Cancer Immunol. Immunother. 66, 1425-1436 (2017)

150. G.L. Beatty, M.H. O'Hara, S.F. Lacey, D.A. Torigian, F. Nazimuddin, F. Chen, I.M. Kulikovskaya, M.C. Soulen, M. McGarvey, A.M. Nelson, W.L. Gladney, B.L. Levine, J.J. Melenhorst, G. Plesa, C.H. June, Activity of mesothelin-specific chimeric antigen receptor $\mathrm{T}$ cells against pancreatic carcinoma metastases in a Phase 1 trial. Gastroenterology 155, 29-32 (2018)

151. A. Schmidts, M.V. Maus, Making CAR T cells a solid option for solid tumors. Front. Immunol 9, 2593 (2018)

152. S. Li, N. Siriwon, X. Zhang, S. Yang, T. Jin, F. He, Y.J. Kim, J. Mac, Z. Lu, S. Wang, X. Han, P. Wang, Enhanced cancer immunotherapy by chimeric antigen receptor-modified $\mathrm{T}$ cells engineered to secrete checkpoint inhibitors. Clin. Cancer Res. 23, 6982-6992 (2017)

153. L. Cherkassky, A. Morello, J. Villena-Vargas, Y. Feng, D.S. Dimitrov, D.R. Jones, M. Sadelain, P.S. Adusumilli, Human CAR T cells with cell-intrinsic PD-1 checkpoint blockade resist tumor-mediated inhibition. J. Clin. Invest. 126, 3130-3144 (2016)

154. L.B. John, C. Devaud, C.P. Duong, C.S. Yong, P.A. Beavis, N.M. Haynes, M.T. Chow, M.J. Smyth, M.H. Kershaw, P.K. Darcy, Anti-PD-1 antibody therapy potently enhances the eradication of established tumors by gene-modified T cells. Clin. Cancer Res. 19, 5636-5646 (2013)

155. J. Borst, T. Ahrends, N. Bąbała, C.J.M. Melief, W. Kastenmüller, CD4(+) T cell help in cancer immunology and immunotherapy. Nat. Rev. Immunol. 18, 635-647 (2018)

156. R.H. Vonderheide, The immune revolution: A case for priming, not checkpoint. Cancer Cell 33, 563-569 (2018)

157. G.L. Beatty, E.G. Chiorean, M.P. Fishman, B. Saboury, U.R. Teitelbaum, W. Sun, R.D. Huhn, W. Song, D. Li, L.L. Sharp, D.A. Torigian, P.J. O'Dwyer, R.H. Vonderheide, CD40 agonists alter tumor stroma and show efficacy against pancreatic carcinoma in mice and humans. Science 331, 1612-1616 (2011)

158. G.L. Beatty, D.A. Torigian, E.G. Chiorean, B. Saboury, A. Brothers, A. Alavi, A.B. Troxel, W. Sun, U.R. Teitelbaum, R.H.
Vonderheide, P.J. O'Dwyer, A phase I study of an agonist CD40 monoclonal antibody (CP-870,893) in combination with gemcitabine in patients with advanced pancreatic ductal adenocarcinoma. Clin. Cancer Res. 19, 6286-6295 (2013)

159. M.H. O'Hara, E.M. O'Reilly, M. Rosemarie, G. Varadhachary, Z.A. Wainberg, A. Ko, G.A. Fisher, O. Rahma, J.P. Lyman, C.R. Cabanski, E.L. Carpenter, T. Hollmann, P.F. Gherardini, L. Kitch, C. Selinsky, T. LaVallee, O.C. Trifan, U. Dugan, V.M. Hubbard-Lucey, R.H. Vonderheide, Abstract CT004: A Phase Ib study of CD40 agonistic monoclonal antibody APX005M together with gemcitabine (Gem) and nab-paclitaxel (NP) with or without nivolumab (Nivo) in untreated metastatic ductal pancreatic adenocarcinoma (PDAC) patients. 79, CT004 (2019)

160. D.J. Sieg, C.R. Hauck, D.D. Schlaepfer, Required role of focal adhesion kinase (FAK) for integrin-stimulated cell migration. J. Cell Sci. 112(Pt 16), 2677-2691 (1999)

161. D.D. Schlaepfer, S.K. Hanks, T. Hunter, P. van der Geer, Integrinmediated signal transduction linked to Ras pathway by GRB2 binding to focal adhesion kinase. Nature 372, 786-791 (1994)

162. H. Jiang, S. Hegde, B.L. Knolhoff, Y. Zhu, J.M. Herndon, M.A. Meyer, T.M. Nywening, W.G. Hawkins, I.M. Shapiro, D.T. Weaver, J.A. Pachter, A. Wang-Gillam, D.G. DeNardo, Targeting focal adhesion kinase renders pancreatic cancers responsive to checkpoint immunotherapy. Nat. Med. 22, 851-860 (2016)

163. J.B. Stokes, S.J. Adair, J.K. Slack-Davis, D.M. Walters, R.W. Tilghman, E.D. Hershey, B. Lowrey, K.S. Thomas, A.H. Bouton, R.F. Hwang, E.B. Stelow, J.T. Parsons, T.W. Bauer, Inhibition of focal adhesion kinase by PF-562,271 inhibits the growth and metastasis of pancreatic cancer concomitant with altering the tumor microenvironment. Mol. Cancer Ther. 10, 2135 2145 (2011)

164. R.J. Akhurst, R. Derynck, TGF-beta signaling in cancer-a doubleedged sword. Trends Cell Biol. 11, S44-S51 (2001)

165. D.R. Principe, B. DeCant, E. Mascarinas, E.A. Wayne, A.M. Diaz, N. Akagi, R. Hwang, B. Pasche, D.W. Dawson, D. Fang, D.J. Bentrem, H.G. Munshi, B. Jung, P.J. Grippo, TGFbeta signaling in the pancreatic tumor microenvironment promotes fibrosis and immune evasion to facilitate tumorigenesis. Cancer Res. 76, 2525-2539 (2016)

166. W. Chen, P. Ten Dijke, Immunoregulation by members of the TGFbeta superfamily. Nat. Rev. Immunol. 16, 723-740 (2016)

167. J.M. Yingling, W.T. McMillen, L. Yan, H. Huang, J.S. Sawyer, J. Graff, D.K. Clawson, K.S. Britt, B.D. Anderson, D.W. Beight, D. Desaiah, M.M. Lahn, K.A. Benhadji, M.J. Lallena, R.B. Holmgaard, X. Xu, F. Zhang, J.R. Manro, P.W. Iversen, C.V. Iyer, R.A. Brekken, M.D. Kalos, K.E. Driscoll, Preclinical assessment of galunisertib (LY2157299 monohydrate), a first-in-class transforming growth factor-beta receptor type I inhibitor. Oncotarget 9, 6659-6677 (2018)

168. D. Melisi, R. Garcia-Carbonero, T. Macarulla, D. Pezet, G. Deplanque, M. Fuchs, J. Trojan, H. Oettle, M. Kozloff, A. Cleverly, C. Smith, S.T. Estrem, I. Gueorguieva, M.M.F. Lahn, A. Blunt, K.A. Benhadji, J. Tabernero, Galunisertib plus gemcitabine vs. gemcitabine for first-line treatment of patients with unresectable pancreatic cancer. Br. J. Cancer 119, 1208 1214 (2018)

169. D. Melisi, A. Hollebecque, D.-Y. Oh, E. Calvo, A.M. Varghese, E.H. Borazanci, T.M. Mercade, F. Simionato, J.O. Park, J.C. Bendell, S.J. Faivre, Y. Zhao, I. Gueorguieva, M. Man, S. Estrem, K.A. Benhadji, M. Lanasa, S.C. Guba, R. GarciaCarbonero, A phase $\mathrm{Ib}$ dose-escalation and cohort-expansion study of safety and activity of the transforming growth factor (TGF) $\beta$ receptor I kinase inhibitor galunisertib plus the anti-PDL1 antibody durvalumab in metastatic pancreatic cancer. 37, 4124-4124 (2019) 
170. A. Leask, D.J. Abraham, All in the CCN family: essential matricellular signaling modulators emerge from the bunker. J. Cell Sci. 119, 4803-4810 (2006)

171. M. Pickles, A. Leask, Analysis of CCN2 promoter activity in PANC-1 cells: regulation by ras/MEK/ERK. J. Cell. Commun. Signal. 1, 85-90 (2007)

172. C. Wenger, V. Ellenrieder, B. Alber, U. Lacher, A. Menke, H. Hameister, M. Wilda, T. Iwamura, H.G. Beger, G. Adler, T.M. Gress, Expression and differential regulation of connective tissue growth factor in pancreatic cancer cells. Oncogene 18, 1073-1080 (1999)

173. T. Aikawa, J. Gunn, S.M. Spong, S.J. Klaus, M. Korc, Connective tissue growth factor-specific antibody attenuates tumor growth, metastasis, and angiogenesis in an orthotopic mouse model of pancreatic cancer. Mol. Cancer Ther. 5, 1108-1116 (2006)

174. L. Richeldi, E.R. Fernandez Perez, U. Costabel, C. Albera, D.J. Lederer, K.R. Flaherty, N. Ettinger, R. Perez, M.B. Scholand, J. Goldin, K.H. Peony Yu, T. Neff, S. Porter, M. Zhong, E. Gorina, E. Kouchakji, G. Raghu, Pamrevlumab, an anti-connective tissue growth factor therapy, for idiopathic pulmonary fibrosis (PRAISE): a phase 2, randomised, double-blind, placebocontrolled trial. Lancet Respir Med (2019)

175. G.J. Doherty, M. Tempero, P.G. Corrie, HALO-109-301: a Phase III trial of PEGPH20 (with gemcitabine and nab-paclitaxel) in hyaluronic acid-high stage IV pancreatic cancer. Future Oncol. (London, England) 14, 13-22 (2018)

176. C.J. Whatcott, C.H. Diep, P. Jiang, A. Watanabe, J. LoBello, C. Sima, G. Hostetter, H.M. Shepard, D.D. Von Hoff, H. Han, Desmoplasia in primary tumors and metastatic lesions of pancreatic cancer. Clin. Cancer Res. 21, 3561-3568 (2015)

177. P.P. Provenzano, C. Cuevas, A.E. Chang, V.K. Goel, D.D. Von Hoff, S.R. Hingorani, Enzymatic targeting of the stroma ablates physical barriers to treatment of pancreatic ductal adenocarcinoma. Cancer Cell 21, 418-429 (2012)

178. S.R. Hingorani, W.P. Harris, J.T. Beck, B.A. Berdov, S.A. Wagner, E.M. Pshevlotsky, S.A. Tjulandin, O.A. Gladkov, R.F. Holcombe, R. Korn, N. Raghunand, S. Dychter, P. Jiang, H.M. Shepard, C.E. Devoe, Phase Ib study of PEGylated recombinant human hyaluronidase and gemcitabine in patients with advanced pancreatic cancer. Clin. Cancer Res. 22, 2848-2854 (2016)
179. S.R. Hingorani, L. Zheng, A.J. Bullock, T.E. Seery, W.P. Harris, D.S. Sigal, F. Braiteh, P.S. Ritch, M.M. Zalupski, N. Bahary, P.E. Oberstein, A. Wang-Gillam, W. Wu, D. Chondros, P. Jiang, S. Khelifa, J. Pu, C. Aldrich, A.E. Hendifar, HALO 202: Randomized phase II study of PEGPH20 plus Nab-Paclitaxel/ Gemcitabine versus Nab-Paclitaxel/Gemcitabine in patients with untreated metastatic pancreatic ductal adenocarcinoma. J. Clin. Oncol. 36, 359-366 (2018)

180. R.K. Ramanathan, S.L. McDonough, P.A. Philip, S.R. Hingorani, J. Lacy, J.S. Kortmansky, J. Thumar, E.G. Chiorean, A.F. Shields, D. Behl, P.T. Mehan, R. Gaur, T. Seery, K.A. Guthrie, H.S. Hochster, Phase IB/II randomized study of FOLFIRINOX plus pegylated recombinant human hyaluronidase versus FOLFIRINOX alone in patients with metastatic pancreatic adenocarcinoma: SWOG S1313. J. Clin. Oncol. 37, 1062-1069 (2019)

181. P. Malekzadeh, A. Pasetto, P.F. Robbins, M.R. Parkhurst, B.C. Paria, L. Jia, J.J. Gartner, V. Hill, Z. Yu, N.P. Restifo, A. Sachs, E. Tran, W. Lo, R.P. Somerville, S.A. Rosenberg, D.C. Deniger, Neoantigen screening identifies broad TP53 mutant immunogenicity in patients with epithelial cancers. J. Clin. Invest. 129, 1109-1114 (2019)

182. V.P. Balachandran, M. Luksza, J.N. Zhao, V. Makarov, J.A. Moral, R. Remark, B. Herbst, G. Askan, U. Bhanot, Y. Senbabaoglu, D.K. Wells, C.I.O. Cary, O. Grbovic-Huezo, M. Attiyeh, B. Medina, J. Zhang, J. Loo, J. Saglimbeni, M. AbuAkeel, R. Zappasodi, N. Riaz, M. Smoragiewicz, Z.L. Kelley, O. Basturk, M. Gonen, A.J. Levine, P.J. Allen, D.T. Fearon, M. Merad, S. Gnjatic, C.A. Iacobuzio-Donahue, J.D. Wolchok, R.P. DeMatteo, T.A. Chan, B.D. Greenbaum, T. Merghoub, S.D. Leach, Identification of unique neoantigen qualities in long-term survivors of pancreatic cancer. Nature 551, 512-516 (2017)

183. M.E. Ijsselsteijn, R. van der Breggen, A. Farina Sarasqueta, F. Koning, N. de Miranda, A 40-marker panel for high dimensional characterization of cancer immune microenvironments by imaging mass cytometry. Front. Immunol. 10, 2534 (2019)

Publisher's note Springer Nature remains neutral with regard to jurisdictional claims in published maps and institutional affiliations. 